\title{
Demographic Engineering and International Conflict: Evidence from China and the Former USSR
}

\author{
Lachlan McNamee and Anna Zhang
}

\begin{abstract}
When and where do states coercively alter their internal demography? We build a theory that predicts under what conditions states alter the demographic "facts on the ground" by resettling and expelling ethno-national populations. We predict that, under particular scope conditions, states will employ demographic engineering to shore up control over (1) nonnatural frontiers, and (2) areas populated by ethnic minorities who are co-ethnics with elites in a hostile power. We then substantiate our predictions using new subnational data from both China and the USSR. Causally identifying the spatially differential effect of international conflict on demographic engineering via a difference-in-differences design, we find that the Sino-Soviet split (1959-1982) led to a disproportionate increase in the expulsion of ethnic Russians and resettlement of ethnic Han in Chinese border areas lacking a natural border with the USSR, and that resettlement was targeted at areas populated by ethnic Russians. On the Soviet side, we similarly find that the Sino-Soviet split led to a significant increase in expulsion of Chinese and the resettlement of Russians in border areas, and that resettlement was targeted at areas populated by more Chinese. We develop the nascent field of political demography by advancing our theoretical and empirical understanding of when, where, and to whom states seek to effect demographic change. By demonstrating that both ethnic group concentration and dispersion across borders are endogenous to international conflict, our results complicate a large and influential literature linking ethnic demography to conflict.
\end{abstract}

Since late August 2017, Burma has engaged in a renewed campaign of violence against its Rohingya minority. After attacks from secessionist Rohingya insurgents in Bangladesh, Burmese soldiers have burned hundreds of villages near the

We thank Avi Acharya, Claire Adida, Michael Albertus, Lisa Blaydes, Songying Fang, Jim Fearon, Jackelyn Hwang, David Laitin, Hans Lueders, Scott Newman, Jean Oi, Jonathan Rodden, Aliya Saperstein, Ken Scheve, Ken Schultz, Mike Tomz, Jeremy Weinstein, and participants in the 2017 Midwest Political Science Association conference, the 2017 Australian Quantitative Political Science Conference, the Stanford China Social Sciences Workshop, Stanford International Relations Workshop, Stanford Migration Ethnicity Race and Nation Workshop, the Higher School of Economics, the 2018 Pacific International Politics Conference, 2018 International Political Science Association Annual Meeting, and the 2018 Peace Science Studies Annual Meeting for valuable comments. Many thanks also to three anonymous reviewers and to the editors of $I O$ for their comments which greatly improved the paper. 
Bangladeshi border and induced over half a million Rohingya to flee. ${ }^{1}$ If recent history is any guide, burnt lands are likely to become new "model villages" exclusively populated by resettled Buddhists from Bangladesh and elsewhere in Burma."

The state-sponsored resettlement and expulsion ${ }^{3}$ of people to alter the ethnonational composition of a region - a phenomenon we define as demographic engineering - is by no means a phenomenon limited to Burma. Scholars have documented a diverse number of cases in which states have sought to engage in demographic engineering. ${ }^{4}$ Insofar as population movement shapes the geographic distribution of ethno-national groups, demographic engineering can alter a state's effective territorial control. In essence, rather than have its territorial borders reflect the distribution of ethno-national groups, demographic engineering can ensure that the distribution of ethno-national groups reflects a state's desired territorial borders.

Yet, for every observed instance of demographic engineering, there are equally many if not more instances where demographic engineering did not occur. Not all states engage in demographic engineering and even those that do are strategic and selective in deciding where, when, and to whom they seek to alter the demographic "facts on the ground." For example, Thailand sought to resettle Thai Buddhists to Malay areas only after the 1950s and its resettlement program has been limited to its four southernmost provinces. It was only in the late sixteenth century that England sought to secure control over Ireland through resettlement and, even then, demographic engineering was limited to Ireland rather than English-controlled areas of Scotland or Wales. Likewise, puzzlingly, despite clashes with India over the Tibetan border in the 1960s and mass resettlement to other border areas of China over the same period, Han resettlement to Tibet was tightly restricted during the Mao era. ${ }^{5}$ Even in the extreme case of Burma, it is clear from satellite maps that, despite ethnic Rohingya being present across Rakhine state, the incidence of village burning has been almost entirely concentrated in a low-lying strip along the southern Burma-Bangladesh border.

While well understood that demographic engineering can occur, our understanding of state-sponsored demographic change is nonetheless characterized by analytical gaps. Why do only certain states seem to engage in demographic engineering and why then only at certain periods of time? Why do such states target particular

1. Estimate provided by Human Rights Watch as of mid-October $2017<$ https://www.hrw.org/blog-feed/ rohingya-crisis>, accessed 13 October 2017.

2. Human Rights Watch 2000.

3. We use the term expulsion rather than forced migration to focus attention on state-sponsored demographic change because forced migration encompasses a broad range of phenomena, including people trafficking and refugee flows - which are beyond the scope of this analysis. The expulsion of an ethnic group from an area is often also defined as ethnic cleansing. See Hägerdal 2017.

4. For example, see Banister 2001; Bookman 1997; Haklai and Loizides 2015; Lustick 1993; McGarry 1998.

5. Indeed, the proportion of Tibetans in Tibet between the 1964 and 1982 censuses dropped only 1.9 percent from 96.6 to 94.7 percent. Recent growing Han predominance in Tibet has instead largely been driven by employment in the tourism industry since the 1990s. See Ma 2011, 52. 
minorities and not others? Finally, why are some areas targeted for demographic engineering and not others? In short, what accounts for the substantial variation in the incidence of demographic engineering over both time and space?

We provide new theory and evidence that can help answer these important and understudied questions. Integrating recent insights into the geopolitics of minority exclusion $^{6}$ and work in international relations on the spatially strategic dimension of international conflict, ${ }^{7}$ we develop a theory of how the strategic dynamics of territorial conflict account for the spatio-temporal incidence of demographic engineering. In the absence of open war, states have historically sought to undermine their rivals by supporting insurgencies among cross-border co-ethnics. ${ }^{8}$ By expelling socalled "fifth column" minorities and reducing their concentration in contested frontiers through an influx of ethnically distinct settlers, demographic engineering can forestall secessionist mobilization and cross-border insurgencies. ${ }^{9}$ However, not all frontiers are alike. Natural borders-which we define as those that are difficult to traverse because of geographic partitions such as mountain ranges or large bodies of water-independently act as obstacles to external attack and unregulated flows of personnel, propaganda, and equipment. ${ }^{10} \mathrm{We}$ therefore contend that, as a strategic response to territorial conflict, demographic engineering will be disproportionately employed by states to shore up control over their most vulnerable frontiers-those that lack natural boundaries and are populated by ethnic minorities who are coethnics with the elites of a hostile power. ${ }^{11}$

Of course, not all states engage in demographic engineering. The scope conditions for our theory are states that (1) have a majority ethnic group inhabiting a core region and an ethnically distinct periphery, and (2) inhabit a regional system in which territorial borders are contested and potentially dynamic. We then provide quantitative evidence that substantiates our theoretical predictions in the context of two important countries that do satisfy these scope conditions: China and the Soviet Union (USSR) during the second half of the twentieth century. Both China and the USSR sought to undermine each other's respective control over frontier areas during the Sino-Soviet split (1959-1982) and both states engaged in a number of resettlement programs and coercive expulsions that substantially altered their ethnic demography over this period. The Sino-Soviet split can be plausibly considered a discontinuous break in

6. Mylonas 2012.

7. For example, see Carter 2010; Goemans and Schultz 2016.

8. See Gleditsch, Salehyan, and Schultz 2008; Lee 2018; Salehyan 2009.

9. Bulutgil 2016; Hägerdal 2017; McNamee 2018.

10. See Keegan 1993; Kitamura and Lagerlöf 2015; Pounds 1972.

11. These insights help resolve the earlier puzzles: Irish Catholics were viewed as allied to Catholic Spain in the wars between England and Spain in the late 1500s and so were targeted for expulsion and resettlement; Malays in southern Thailand were seen as receiving secessionist support from elites in newly independent Malaysia after the 1950s; Tibet, while contested, has never had a cross-border insurgency thanks to the largely impassable Himalayas; and northern Rakhine state is also largely mountainous so cross-border activity has been concentrated in the low-lying southern Burma/Bangladesh border. 
international relations between two contiguous states. We exploit the break in relations between the USSR and China in 1959 and use a difference-in-difference design to cleanly test our theoretical predictions about the incidence of state-sponsored demographic change.

Our difference-in-difference results indicate that the breakdown of Sino-Soviet relations led to the resettlement of 300,000 people and a 40 percent additional increase in the percentage of ethnic Han in each Chinese province bordering the USSR. Within the contested province of Xinjiang since 1952, we find that Han settlement during the Sino-Soviet split was particularly targeted at those counties in Xinjiang populated by Russians and lacking a natural border with the USSR. We further find that the Sino-Soviet split led to the expulsion of a substantial proportion of the ethnic Russian population of Xinjiang, and that this drop was most significant in Xinjiang counties lacking a natural border with the USSR. On the Soviet side of the border, our difference-in-difference estimates similarly indicate that demographic engineering during the Sino-Soviet split was targeted at border areas and those populated by more Chinese. These results together substantiate our core theoretical predictions regarding the spatio-temporal incidence of demographic engineering.

We therefore advance the literature on a number of fronts. Theoretically, we develop the nascent and neglected field of political demography. ${ }^{12}$ By bringing the state back into the study of subnational demographic change, we advance our analytical understanding of where, when, and to whom mass resettlement or expulsions are particularly likely to occur. Empirically, by exploiting a break in relations between two contiguous states and measuring its effects on subnational demography via a difference-in-difference design, we provide the first well-identified evidence for the conditions under which states use demographic engineering. Finally, by endogenizing the distribution of ethno-national groups to international relations, we complicate a large literature linking partitioned or concentrated ethnic groups to the diffusion of conflict. ${ }^{13}$ Our results suggest that both the presence of partitioned ethnic groups and ethnic group concentration are endogenous to past international conflict and the incidence of demographic engineering, indicating that existing findings using ethnic demography as an independent variable may be confounded by omitted variable bias. As such, we caution against the current tendency in quantitative work to implicitly treat the distribution of ethnic groups as exogenous.

\section{Literature Review}

Scholars of international relations have long recognized the importance of territorial borders-institutions that have emerged to allow states to coordinate territorial 
claims. ${ }^{14}$ Yet, scholars have only relatively recently paid closer attention to the process whereby borders are consolidated by states.

On the one hand, border consolidation has been shown to be a function of a dyadic process of interstate bargaining and conflict over formal territorial claims. ${ }^{15}$ But the development of stable borders can also be a function of unilateral decision making by states. ${ }^{16} \mathrm{~A}$ growing literature in the study of civil war has detailed how armed groups can use migration to consolidate control over territory. ${ }^{17}$ In a similar vein and with respect to the movement of ethnic groups specifically, it has long been theorized that states can unilaterally consolidate control over territory by altering the demographic "facts on the ground." Through ethnic cleansing and violence, states can remove minorities that can potentially aid a challenger. ${ }^{18}$ Populating a frontier with co-ethnics viewed as loyal to the state also allows states to rapidly consolidate control over contested territory. ${ }^{19}$

The literature on the connection between demographic change and territorial conflict has nevertheless been characterized by empirical and theoretical challenges. Theoretically, while we know that states can engage in demographic engineering, we have less understanding of the conditions under which this is particularly likely to occur. As a notable exception, Harris Mylonas has advanced our understanding of the timing of demographic engineering. ${ }^{20}$ His motivating assumption is that elites in the age of nationalism are driven by a "homogenizing imperative," and that "nation-building is not considered complete until there are no threatening noncore groups within their state." 21 Mylonas predicts that when geopolitical relations between states sour, threatening fifth-column ethnic groups supported by hostile power will be expelled or coercively assimilated through internal colonization.

We build on Mylonas's insights into the timing of minority exclusion to offer a more general theory for understanding when, where, and why demographic engineering occurs. We specifically relax the assumption that elites are driven by a homogenizing national imperative and instead theorize demographic engineering as a statebuilding strategy deployed to consolidate territory. This perspective can offer broader analytical leverage because demographic engineering has been undertaken by states such as China in newly conquered territories prior to the age of nationalism—whether by the Qin, Ming or Qing dynasties. Demographic engineering has

14. See Carter and Poast 2015; Goemans 2006; Simmons 2005. Dispute over the location of borders has been shown to be a leading cause of international conflict—see Kocs 1995; Senese 2005; Vasquez 1993; Vasquez and Henehan 2001. Historical territory may have a particularly indivisible quality, giving rise to bargaining failure.

15. See Fravel 2008; Goemans 2006; Goemans and Schultz 2016; Huth 1998.

16. Carter 2010.

17. Balcells and Steele 2016; Downes 2008; Greenhill 2008; Hägerdal 2017; Lichtenheld 2018; Steele 2011; Zhukov 2015.

18. Balcells and Steele 2016; Hägerdal 2017; Valentino, Huth, and Balch-Lindsay 2004.

19. McNamee 2018.

20. Mylonas 2012.

21. Ibid., 24. 
historically tended to occur alongside and as a complement to a broader project of territorial consolidation. For example, in addition to currently expelling the Rohingya and resettling Buddhists, the Burmese state has recently fortified its border with Bangladesh with a new fence, an influx of security forces, and land mines. Probing the strategic dynamics of territorial conflict will hence offer insight into not just when but where states engage in coercive territorial consolidation more generally and demographic engineering specifically.

Empirically, analyses of demographic engineering have tended to be characterized by the dual challenges of data collection and causal identification. Given the paucity of historical subnational demographic data, analyses of demographic engineering tend to be limited to case typologies, ${ }^{22}$ focused analyses of a small number of cases ${ }^{23}$ or cross-country regressions using binary indicators. ${ }^{24}$ To uncover otherwise hidden spatio-temporal dynamics structuring the incidence of demographic engineering, however, it is essential that we move to a more disaggregated level of analysis that can measure state-sponsored migration and dynamic change in ethnic composition in a more systematic way. ${ }^{25}$ Most individual cases are overdetermined because ethnic group expulsions and state-sponsored resettlement can be undertaken for a number of reasons, including to reduce perceived overpopulation in urban areas or to develop sparsely populated lands for modern agriculture. ${ }^{26}$ So to credibly identify the connection between territorial conflict and state-sponsored demographic change, we require an empirical strategy that can exploit a plausibly exogenous increase in territorial conflict and measure its effects using a panel of subnational ethnic demographic change. We do precisely this by compiling new subnational data and exploiting the break in relations between China and the USSR over the Sino-Soviet split (1959-1982) to credibly test a number of theoretical hypotheses relating territorial conflict and demographic change.

\section{Theory}

Why is demographic engineering an effective strategy for states to consolidate territory? First, by changing the demographic "facts on the ground" through the cleansing of non-nationals or the resettlement of co-nationals, states can extend their claim to contested territory by making dyadic border changes more difficult. Insofar as

22. See, for example, Bookman 1997; McGarry 1998; Morland 2014.

23. See, for example, Banister 2001; Bleuer 2012; Han and Mylonas 2014; Hazarika 2001; Lustick 1993; Martin 2001; Natali 2015.

24. See, for example, Bulutgil 2016; Carter 2010; Huth 1998; Mylonas 2012. See McNamee 2018 and Hägerdal 2017 for recent notable exceptions using binary indicators of mass resettlement and ethnic cleansing respectively at the subnational and subgroup level that, nonetheless, because of data limitations do not track dynamic change in demographic composition.

25. Systematic data collection picks up the many cases in which demographic engineering did not occur while geographic disaggregation can uncover variation concealed in dyadic or group-based analyses.

26. Fearon and Laitin 2011. 
population movement shapes the geographic distribution of allegiant groups, demographic engineering can calcify territorial borders by engendering ethno-national homogenization along a contested frontier. ${ }^{27}$

Second, demographic engineering can consolidate territorial borders by effectively forestalling cross-border insurgencies and minority secessionism. A large literature has shown that more concentrated minority groups are at a higher risk of engaging in civil conflict ${ }^{28}$ since concentration facilitates minority collective action. ${ }^{29}$ Partitioned ethnic minorities are particularly at risk of engaging in secessionist conflicts as a result of the funding, territory, and arms provided by cross-border kin. ${ }^{30}$ By reducing minority concentration in general and the dominance of partitioned minorities in vulnerable border zones, demographic engineering can impede successful cross-border insurgencies. ${ }^{31}$

Instead of populating a frontier with new settlers, states could instead try to extend their effective control by garnering the loyalty of indigenous populations. One important reason that states would seek to demographically engineer frontier regions rather than facilitate assimilation is related to the dynamics of territorial conflict. States in low-information conflictual contexts use ethnic identifiers to assess the likely political loyalties of populations. ${ }^{32}$ Ethnic minorities who are co-ethnics with politically powerful elites in a foreign power are viewed as "fifth columns" allied to a hostile foreign power and are thus targeted for repression rather than assimilation, ${ }^{33}$ which usually requires a substantial period of time and is thus an ill-suited strategy to pursue in response to rising conflict. The expulsion of an ethnic minority and the demographic dilution of its lands with new settlers are therefore likely to simultaneously occur to minorities who are co-ethnics with elites in a hostile foreign power. ${ }^{34}$

However, in all but the most extreme cases, not all members of a minority are generally targeted for cleansing and not all lands along a border are targeted for resettlement. Given the spatially strategic dimension to territorial conflict, the incidence of demographic engineering should vary not only by ethnicity but also by space. States can undermine their rivals by facilitating the systematic violation of their border by nonstate actors seeking to secede from or overthrow the government and

27. See Bookman 1997; Haklai and Loizides 2015; Lustick 1993; McGarry 1998; Morland 2014.

28. For example, see Cornell 2002; Horowitz 1985; Toft 2003.

29. Morelli and Rohner 2015; Weidmann 2009.

30. See Salehyan 2009.

31. Given that similar collective targeting dynamics can be found in ideological conflicts such as the Spanish Civil War, Balcells and Steele 2016 make a compelling case that ethnic cleansing should be considered just one type of a broader category: political cleansing.

32. See Blaydes 2018; Kalyvas 2006.

33. See Bulutgil 2016; Han and Mylonas 2014; McNamee 2018; Mylonas 2012.

34. This theoretical prediction differs from Mylonas who theorizes forced migration and internal colonization as substitute strategies for either excluding or assimilating a fifth-column ethnic group into the nation. Given that expulsions and internal resettlement both dilute the demographic dominance of a fifth column in a territory, however, our state-building framework predicts that they are rather complementary strategies for consolidating contested territory. 
so the presence of hostile neighbors tends to weaken state capacity in frontier areas. ${ }^{35}$ As a remedial response, we expect demographic engineering to be particularly prevalent in border zones between hostile states.

We also theorize that border segments that follow natural boundaries- those that are difficult to traverse because of geographic partitions such as mountain ranges or large bodies of water - are less likely to be the site of demographic engineering. ${ }^{36}$ To be sure, political geographers have recently downplayed the notion that nature structures political boundaries ${ }^{37}$ and we should be skeptical of claims that some borders are more "focal" or better reflect the distribution of pre-existing ethno-national groups. Even in the canonical case of the French Pyrenees, it is far from clear that there is anything particularly focal or predetermined about a border delimited to follow a particular mountain ridge in a large mountain range and contemporary national divisions either side of the Pyrenees were the product of the French and Spanish border delimitation. ${ }^{38}$

Although cognizant that all social boundaries are constructed by humans and are thus nonnatural in some basic sense, we must allow analytical space for the strategic role that geography plays in military conflict. As John Keegan's A History of Warfare details, all skilled military tacticians throughout history have necessarily taken into account terrain and climate in warfare. ${ }^{39}$ Specifically, borders delimited to follow mountain ranges or large bodies of water are easier to defend from aggressors. ${ }^{40}$ For this reason, regions with large rivers and mountain ranges such as the European Alps or the Asian Himalayas are particularly likely to be divided between a large number of states because the presence of geographic divisions in part makes it less likely that any single state could militarily absorb all of their regional competitors. ${ }^{41}$

For this reason, we propose that state borders that follow geographic features should above all be understood as strategically distinct from "nonnatural" borders. Natural borders present geographic obstacles to communication, trade, and transport between states and so can bolster the stability of borders by both forestalling unregulated cross-border insurgencies and by reducing the likelihood of a successful external attack. ${ }^{42}$

35. Lee 2018.

36. For a survey of the intellectual history of distinguishing between natural and nonnatural borders based on whether or not they follow topographical features, see Fall 2010; Pounds 1972.

37. For example, Fall 2010

38. Sahlins 1989.

39. Keegan 1993.

40. Pounds 1972.

41. Kitamura and Lagerlöf 2015.

42. In this sense, although we use the terms natural and nonnatural borders to refer to an ideal type distinction, the naturalness of a border should be considered a continuous function of the ease of its crossing. Specifically, given the greater difficulty of crossing mountains relative to rivers, mountain borders should therefore be considered more "natural" than river borders and higher mountains more "natural" than lower ones. 
TABLE 1. Geographic conditions predicting the likelihood of demographic engineering

\begin{tabular}{lll}
\hline Conditions & Nonnatural border & Natural border \\
\hline Hostile relations & High & Low \\
Nonhostile relations & None & None \\
\hline
\end{tabular}

Because demographic engineering is a response to territorial weakness, we expect it to be particularly extreme in areas where a state's territorial control is most vulnerable to challenge from external actors - nonnatural border zones and those populated by fifth-column ethnic minorities. In short, the timing of demographic engineering in border zones is shaped by the onset of hostile relations between two contiguous states while the location of demographic engineering is shaped by the location of politically influential partitioned ethnic groups and nonnatural borders. The two-by-two tables corresponding to our theoretical predictions are presented in Tables 1 and 2.

In other words, we hypothesize that:

H1: States will target demographic engineering at border zones contiguous with a hostile foreign power.

H2: States will target demographic engineering at minorities who are co-ethnics with elites in a hostile power rather than other minorities.

\section{H3: States will disproportionately target demographic engineering at nonnatural border areas with a hostile power.}

An alternative hypothesis is that, rather than shore up nonnatural frontiers with the advent of hostile relations, states would instead seek to shore up control over areas characterized by formal border disputes. Although unresolved territorial claims may worsen tensions between countries, geographic disaggregation of territorial disputes can reveal quite different conflict dynamics than dyadic regressions would suggest. ${ }^{43}$ In this respect, even if an unresolved territorial dispute led to a conflict between states, where states would target demographic engineering in response is a separate theoretical question. We have theorized demographic engineering as a response not to dyadic territorial disputes per se but rather to the threat of crossborder and secessionist insurgencies. Given that military vulnerability is unrelated to the age of a border or the presence of a formally disputed boundary, we do not expect that these factors play as important a role in structuring the spatial incidence of demographic engineering in border zones. An anti-hypothesis to our theory is that: 
H4: Border areas with formally disputed boundaries are more likely than other border areas in a conflict to experience demographic engineering.

TABLE 2. Ethnicity conditions predicting the likelihood of demographic engineering

\begin{tabular}{lll}
\hline Conditions & Nonnatural border & Natural border \\
\hline Fifth-column minority & High & Low \\
Non-fifth-column minority & None & None \\
\hline
\end{tabular}

We now test our theoretical predictions in the context of demographic engineering in China and the USSR during the Sino-Soviet split (1959-1982). China and the USSR are particularly apposite countries to study the incidence of state-sponsored demographic change since both countries satisfy two important scope conditions for our theory. First, they are both characterized by a majority ethnic group inhabiting a core geographic region. Unlike in much of the West, the question of minority secessionism is thus a central policy concern. ${ }^{44}$ Second, unlike in sub-Saharan Africa or Latin America, international borders were highly contested and dynamic in Asia during the twentieth century. ${ }^{45}$ Given that these two scope conditions are satisfied, we therefore see the recent history of China and the USSR as particularly fruitful sites to understand how states consolidate control over ethnically heterogeneous and contested frontiers.

\section{Historical Context}

China's borders have almost all contracted since the late imperial era. The only boundary between Russia and China that has remained constant since 1820 is a small portion of the northern border running along the Argun river. After a series of military defeats in the 1800 s, China ceded a substantial amount of territory to Russia and Russian troops facilitated effective Mongolian independence in the early twentieth century. (The appendix provides further historical detail on the progressive development of the Sino-Russian border over this period).

At the time of Chinese Communist victory in 1949, the broad contours of the China-USSR border were thus fairly well defined as a result of a series of treaties

44. Our theory, however, would be relevant for predicting the incidence of demographic engineering in Western states in the past such as the United States during the nineteenth century or weaker contemporary Western states such as Spain or Italy, where during the late twentieth century both states sought to combat secessionism.

45. See Darden and Mylonas 2016; Herbst 1990. This scope condition is a relevant factor with respect to state building more generally. For example, see Herbst 1990; Tilly 1990. State building can engender ethnic homogenization through mechanisms other than the movement of population, for example, through the provision of mass education. See Darden and Mylonas 2016. 
and protocols concluded over the prior century. However, the new Chinese Communist government cast uncertainty on the legitimacy of China's borders given that they were the result of "unequal" treaties signed during a century of Chinese weakness. Frontiers clearly defined by past treaties were all potentially renegotiable after 1949 and the subject of revanchist claims. ${ }^{46}$ Ambiguities and contradictions in past treaties rendered a large portion of the border between the USSR and China under dispute.

Tensions largely unrelated to territorial disputes, however, began to rise between the USSR and China throughout the late 1950s, culminating in the Sino-Soviet split of $1959 .{ }^{47}$ The origins of the split can be traced back to both ideology and geopolitics. Mao forcefully disagreed with Nikita Khrushchev's "Secret Speech" of 1956 that vehemently denounced Stalin's cult of personality and with Khrushchev's general policy of "peaceful co-existence" with the United States. Beyond these more abstract ideological differences, USSR and Chinese geopolitical interests also began to diverge in the late 1950s. The USSR continued to seek a warm-water port on the Pacific and Khrushchev proposed the construction of a joint submarine flotilla and long-wave radio transmitter on Chinese territory in 1958. Mao rebuffed the proposal. He saw it as evidence of the return of historical Soviet designs on Chinese territory and a form of "red imperialism." Mao also continued to seek Taiwanese reunification via military force whereas the USSR, fearing nuclear war with the United States, was reluctant to commit forces in support of this endeavor. These strategic differences ultimately manifested in the Quemoy incident of 1958 when, without informing the USSR in advance, China began to shell the Taiwanese islands of Quemoy and Matsu, taking the USSR and the United States to the brink of nuclear war.

Trust between the USSR and China finally broke down completely in 1959. The USSR viewed the Quemoy incident as evidence that China could not be trusted with nuclear weapons and stopped providing nuclear assistance to China in June 1959. The USSR also took a neutral stance on the Sino-Indian border clashes of August to October 1959, causing much consternation in Beijing. In a vitriolic October meeting between Khrushchev and top Chinese leaders, well known as the turning point in the Sino-Soviet split, ${ }^{48}$ USSR neutrality over the recent SinoIndian clashes proved a hotly contested sticking point. Although Western intelligence forces became aware of the Sino-Soviet split only in 1960 as the USSR publicly withdrew all its technical advisors from China, it is increasingly clear that 1959 represents the key year when Sino-Soviet relations broke down. ${ }^{49}$ As Jian Chen puts it, "the Sino-Indian dispute, and the beginning of the Sino-Soviet split combine to mark

46. An 1973. Ultimately, a few years after the Sino-Soviet split began in 1963, Chinese state media outlets began to publicly press claims to large swaths of historically Chinese territory in the USSR including the southeastern area of Siberia, Vladivostok, and Central Asia.

47. See Chen 2006; 2010.

48. Chen 2010.

49. Lüthi 2010. 
the year 1959 as one of unusual significance, a year in which a new and very different chapter in the global Cold War began to unfold." 50

Chinese domestic policy altered over 1959 to reflect heightened wariness of Soviet influence in China. This included banning the use of the Soviet Cyrillic alphabet in 1959 and sealing the Xinjiang border from the USSR in $1959 .{ }^{51}$ The central government also sought to strengthen its control over border regions by engaging in expulsions of Russians and mass resettlement of Han to the frontier.

Many Chinese residents along the Soviet border had been Soviet citizens in the 1930s when central Chinese authority was absent and still retained ties with coethnics across the border. Mao feared that Soviet influence over ethnic minorities could be used to "detach" border regions from China. ${ }^{52}$ To better consolidate its territorial control, China placed pressure on the significant cohort of Soviet citizens in China, numbering over 100,000 in Xinjiang alone, to leave Chinese territory. USSR citizens in Xinjiang saw their property and other legal rights progressively curtailed in 1959 and a large number were abruptly dismissed from work in state enterprises..$^{53}$ By the end of 1959 more than 88 percent of registered USSR citizens in Xinjiang had been repatriated. ${ }^{54}$

China began to escalate expulsions of Chinese nationals who it viewed as allegiant to the USSR. The Sino-Soviet split led to a significant reduction in Xinjiang's ethnically Russian minority. Qualitative evidence suggests that this reduction is most likely the result of expulsion of dual nationals. According to the CCP Director of Foreign Affairs in Xinjiang, Deng Liqun, between 1954 and 1963, the total number of dualnational ethnic Russians forcibly repatriated to the Soviet Union ranged from 1,968 to 35,922 , which corresponds to our estimate of a total 8,000 decline in the ethnic Russian population resulting from the Sino-Soviet split.

Meanwhile, the mass resettlement of Han Chinese laborers and farmers to frontier regions was underway. The strategy of diluting the dominance of non-Han individuals in border regions was colloquially called "mixing sand." Mass migration was achieved through a number of government campaigns that implored Han youth to go and support China's borderlands and emphasized the ethical and ideological virtues of those who "elected" to resettle. Many of these settlers in Xinjiang, Yunnan, and elsewhere in China were absorbed into state farms. These state farms, run by paramilitary organizations such as the Xinjiang Production and Construction Corps (XPCC or bingtuan), had their own schools, medical services, and government structures, and were almost entirely segregated from the local

50. Chen 2006, 101.

51. An 1973, 72. The Soviets also later charged that the Chinese side began to initiate hostile border incidents and skirmishes in 1959. See Robinson 1972, 1177.

52. Mao 1974, 190-91.

53. Ginsburgs 1978, 70.

54. Fravel 2008, 104. 
population. Approximately 80 percent of Han migrants to Xinjiang during the Mao era were assigned to different units and enterprises of the XPCC. ${ }^{55}$

The focus of territorial threat and consequently XPCC settlement was Xinjiang's northern border with the USSR. Unlike the largely impassable Tian Shan mountains forming the southern border, the northern border, first defined in 1860 to connect existing Chinese sentry stations in low-lying pasture land, did not follow a natural boundary (Figure 2). Concerns about Soviet infiltration across the northern border in the late 1950s and early 1960s were widespread in official and academic sources in China. Soviet authorities were reportedly very active at facilitating cross-border personnel and propaganda flows from Soviet Kazakhstan. In response the Chinese government established a cordon sanitaire along the northern half of the Sino-Soviet border in Xinjiang in 1962 and allocated much of the borderland to the XPCC settlers. ${ }^{56}$

The early 1980s proved a watershed both for domestic policy in China and for Sino-Soviet relations. The election of Ronald Reagan in the United States in November 1981 prompted a strategic rethink in China and the USSR. Reagan's aggressive support of weapons sales to Taiwan, the mujahedeen in Afghanistan, and the general reassertion of US military power abroad prompted China and the USSR to take their first tentative steps toward reconciliation. Leonid Brezhnev offered a conciliation to China in March 1982 and negotiations between China and the USSR ensued over the rest of the year. These talks culminated in an agreement at the end of 1982 that re-established cross-border trade and resumed Sino-Soviet diplomatic relations at the vice-ministerial level. An intensely conflictual period in SinoSoviet relations was, at last, over.

\section{Data}

We predicted that the timing of demographic engineering is shaped by the onset of hostile relations between two contiguous states but its location depends on where politically influential partitioned ethnic groups and nonnatural borders are. In our specific context of study, the two ethnic groups of interest are the Han and Russians, both of whom constituted the majority and politically dominant ethnic group in China and the USSR respectively. The Sino-Soviet split (1959-1982) constitutes the onset of hostile relations. Our hypotheses regarding natural and nonnatural borders are tested by exploiting geographic differences along the border in Xinjiang (Figure 2).

55. White 1979. The XPCC was regarded as a loyal bastion of Han power in Xinjiang. Internal intelligence documents from 1962 reveal that, while the People's Liberation Army (PLA) was expected to engage USSR battalions in any future conflict, XPCC settlers were expected to form militias to pacify unrest among autochthonous minorities.

56. It specifically ordered the XPCC to systematically increase the number of state farms and form a "belt" of agriculture along the Xinjiang-Kazakhstan border to prevent cross-border personnel flows and Soviet infiltration. 
We compiled novel panel data sets at both the provincial and county level in China. We test our hypotheses primarily in the context of China because of data availability. However, later we detail how similar patterns of demographic change can be observed in the former USSR. The Chinese province-year panel is an unbalanced panel of twenty-nine provinces over 1949-1985 based on data from the Compilation of Population Statistics of the People's Republic of China in the same period. These data are based on historical official household registration information from the Ministry of Public Security and have been standardized to reflect 1985 provincial boundaries.

The major sources of error in the data are under counting and double counting. ${ }^{57}$ Because locality cadres are evaluated based on their ability to provide social services to their registered population only, it is not uncommon for individuals to spend long periods of time in unofficial status, since a locality under resource constraints may be reluctant to register a great number of new residents. Moreover, migrants who spend a substantial period of time in two localities in one year are sometimes doubled counted by both localities. These measures exclude military personnel movements, temporary migrants, and unofficial migrants. However, we can be reasonably assured that longterm unofficial interprovincial migration was negligible until the early 1980s because the absence of a market economy meant that unofficial migrants would have had no ability to live independently from the Chinese state.

The fact these data were published in the late 1980s, generally regarded as the most politically open period in modern Chinese history and a time when government manipulation of official population statistics was minimal, ${ }^{58}$ means that these reported household registration numbers constitute the best available data on historical population changes in China. ${ }^{59}$ Reflecting the political openness of the early reform period, the data clearly reflect politically sensitive changes in population such as the precipitous rise in deaths during the Great Leap Forward and its migration estimates are consistent with flows based on both migrant census surveys ${ }^{60}$ and decennial census data. ${ }^{61}$

Our main dependent variables are yearly inward migration and the total population of each province. We primarily look at inward rather than net migration because net migration is also affected by outward migration flows which, as we show, is shaped by geopolitical threat in other ways. We include total population as a dependent variable so we are able to capture changes to both stock and flows of population.

Our secondary source for the province-year panel is the China Statistical Data Compilation (1949-2003). These data are based on information provided by the National Bureau of Statistics. From this data source, we constructed covariate measures of province-year education (number of primary schools), infrastructure

\author{
57. Banister 1991. \\ 58. Li 1985. \\ 59. Banister 1991. \\ 60. Liang and White 1996. \\ 61. Banister 1991.
}


development (length of highways), and economic development (real GDP and gross industrial output). Summary statistics for all these variables are available in Table A.1 in the appendix.

China has four provinces bordering the USSR—Jilin, Inner Mongolia, Xinjiang, and Heilongjiang - and twenty-five provinces not bordering the USSR. Figure 1 provides a map of the provinces. We code the Sino-Soviet split as starting from 1959 and ending at the end of 1982.

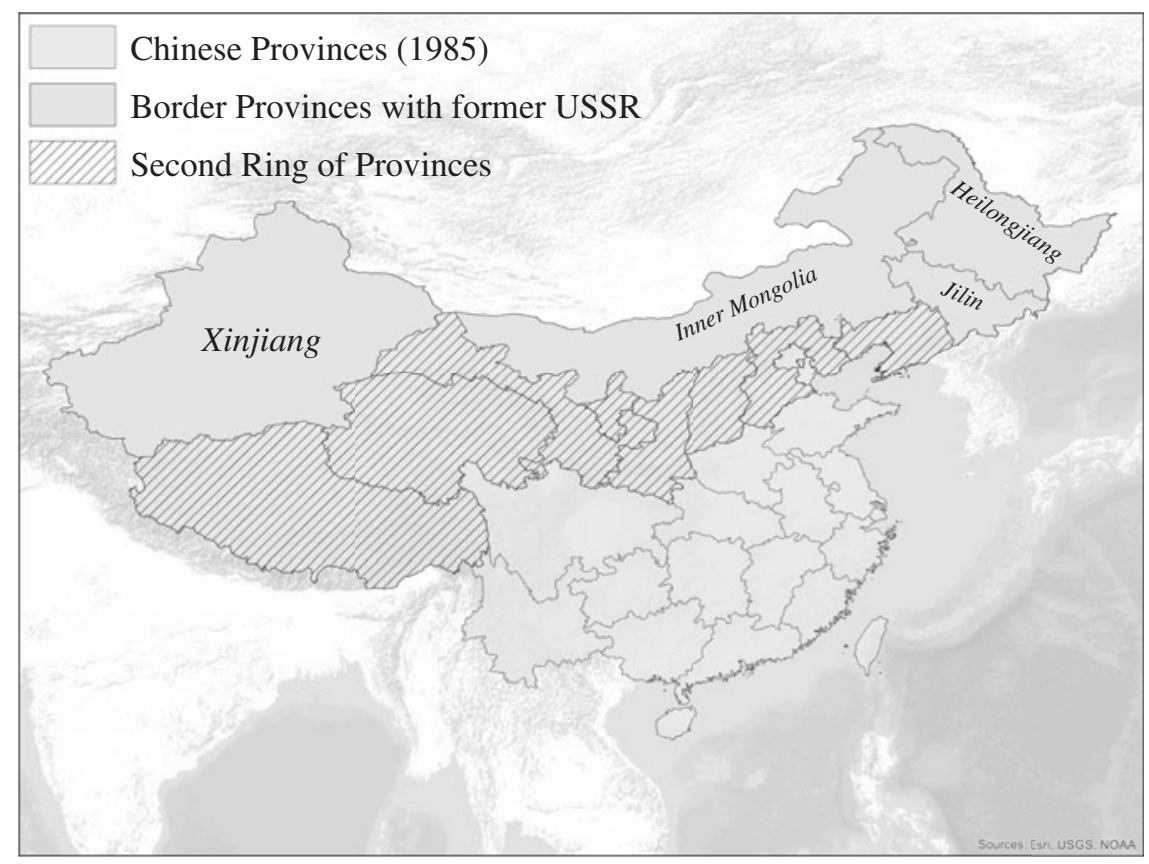

FIGURE 1. Provinces of the People's Republic of China

We are aware that one potential violation of the parallel trend assumption may come from spatially differential effects of the Great Leap Forward campaign (1958-62). ${ }^{62}$ Despite this concern, the Great Leap Forward does not represent a plausible confounder for our analysis because famine-induced migrants were considered "vagrants" or "blind flow" (mangliu) by the Chinese government and were thus not counted as official migrants. ${ }^{63}$ To control for any residual effects of the Great Leap, we also control for measures of province-year death rates, per capita grain

62. The Great Leap Forward was a political campaign from 1958 to 1962 that organized rural households into collectivized communes. Poor incentives and bad weather caused approximately 30 million deaths.

63. The memoir of a southern Chinese intellectual, Li Wenshu, testifies to the difficulty of official registration with the local government in Inner Mongolia. When Li arrived in Inner Mongolia to seek food and employment in 1961, no official dared register him because of a central government order that prohibited 
production, and per capita grain production growth that Meng, Qian, and Yared recently constructed in their analysis of excess mortality during the Great Leap Forward. ${ }^{64}$ As a robustness check, we also show that there was a significant reduction in provincial population and migration to the borderlands as the Sino-Soviet split ended in 1982, which drops all years from the Great Leap Forward. Provincial heterogeneity during the Great Leap Forward is not a confounder for our results within the province of Xinjiang or within the USSR.

Finally, we measure provincial ethnic composition change using information from the Chinese census. We measure the proportion of Han Chinese by province in each of the 1953, 1982, and 1990 censuses. ${ }^{65}$

For the Xinjiang county-year panel, our data sources are the 1952 Population Statistics of Minorities in China and the Xinjiang Uyghur Autonomous Region Statistical Yearbooks dating back to $1963 .{ }^{66}$ Such data have not been compiled before and document politically sensitive changes in population in Xinjiang. ${ }^{67}$ The data in the yearbooks are based on official household registration information from the Xinjiang Ministry of Public Security.

For every county (based on 1952 boundaries) in Xinjiang in every year between 1952 and 1985 to match the time frame of the provincial panel, we coded (1) average county population, (2) number of Han Chinese, (3) number of Uyghurs, (4) number of Kazakhs, (5) number of Hui, (6) number of Kyrgyz, (7) number of Russians, and (8) the number of XPCC settlers. Some counties experienced border changes over time but this was almost always the result of a new county being created within an old county so it was relatively straightforward to match post1952 county data to 1952 county boundaries. ${ }^{68}$ These data, though having their limitations, ${ }^{69}$ represent the best historical source on population changes in Xinjiang.

We have included the two-by-two tables corresponding to the application of our general theoretical predictions to the Xinjiang case in the appendix (Tables A.4-5). We coded natural borders as those that were delimited to follow the Tian Shan mountain range and nonnatural borders as those that were originally

the resettlement of any vagrant without a document. Li was ultimately forced to leave Inner Mongolia in 1962. See Li 2017.

64. Meng, Qian, and Yared 2015.

65. We do not include the 1964 Chinese census in our analysis as it was plagued by mismanagement and so tends to be excluded from statistical analyses. Including 1964, however, does not change our results (see Supplementary Materials B).

66. The pre-1963 Xinjiang yearbooks do not contain county-level data. As such, there is a nine-year gap in our Xinjiang county panel between 1953 and 1962.

67. The yearbooks are available at the University of Washington; this is the only publicly available source for these data worldwide.

68. This is because new counties were created through subdivision. For example, county A would be subdivided into counties $\mathrm{B}$ and $\mathrm{C}$ in later years of the panel and then populations would be reported separately for counties $\mathrm{B}$ and $\mathrm{C}$. By aggregating the populations of $\mathrm{B}$ and $\mathrm{C}$, we can track population change across all the years of the data using county A's borders.

69. Chief among which are that the data do not capture flows of military personnel or illegal/temporary migrants. There has been a significant increase in the unofficial "floating" population of Xinjiang since the market reforms of the 1980s. 
delimited to follow historic Chinese sentry stations. To ensure our results are not being driven by the dichotomization of natural and nonnatural borders in Xinjiang, we also include specifications using a continuous measure of the "naturalness" of the border measured by mean altitude.

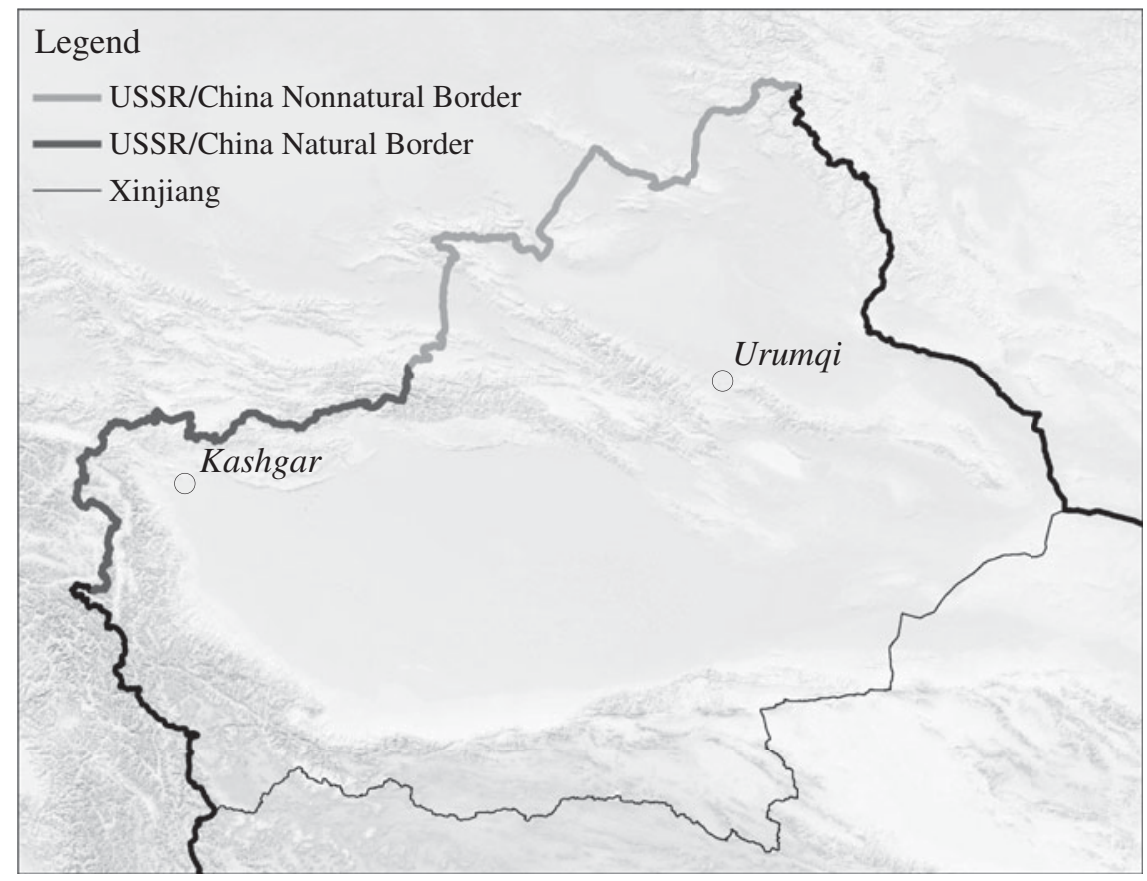

FIGURE 2. The province of Xinjiang, China, and its natural and nonnatural borders with the USSR

We created three different measures of proximity to Xinjiang's nonnatural northern border with the USSR. First, we created (1) a binary measure of whether a county is a northern border county, (2) whether a county lies in northern Xinjiang, and (3) the distance of all counties to Xinjiang's northern border with the USSR. Northern counties of Xinjiang lie in the Dzungar Basin and southern counties in the Tarim Basin - the two are separated by a mountain range widely recognized as a politically significant divider between northern and southern Xinjiang (Figure 2). ${ }^{70}$ Figure 3 illustrates these three measures in space. To the extent that all three of these measures

70. A common saying in contemporary Xinjiang is BeiHan NanWei-that the north of Xinjiang is populated by Han and the south by Uyghurs. This patterning of ethnic demography originated in this increase in Han driven by proximity to nonnatural borders with the USSR in Xinjiang's north. 
predict an increase in Han and XPCC settlement and a reduction in the ethnically Russian population during the Sino-Soviet split, we can be assured that the Chinese state was particularly focused on consolidating its control over areas of Xinjiang lacking a natural border with the USSR.

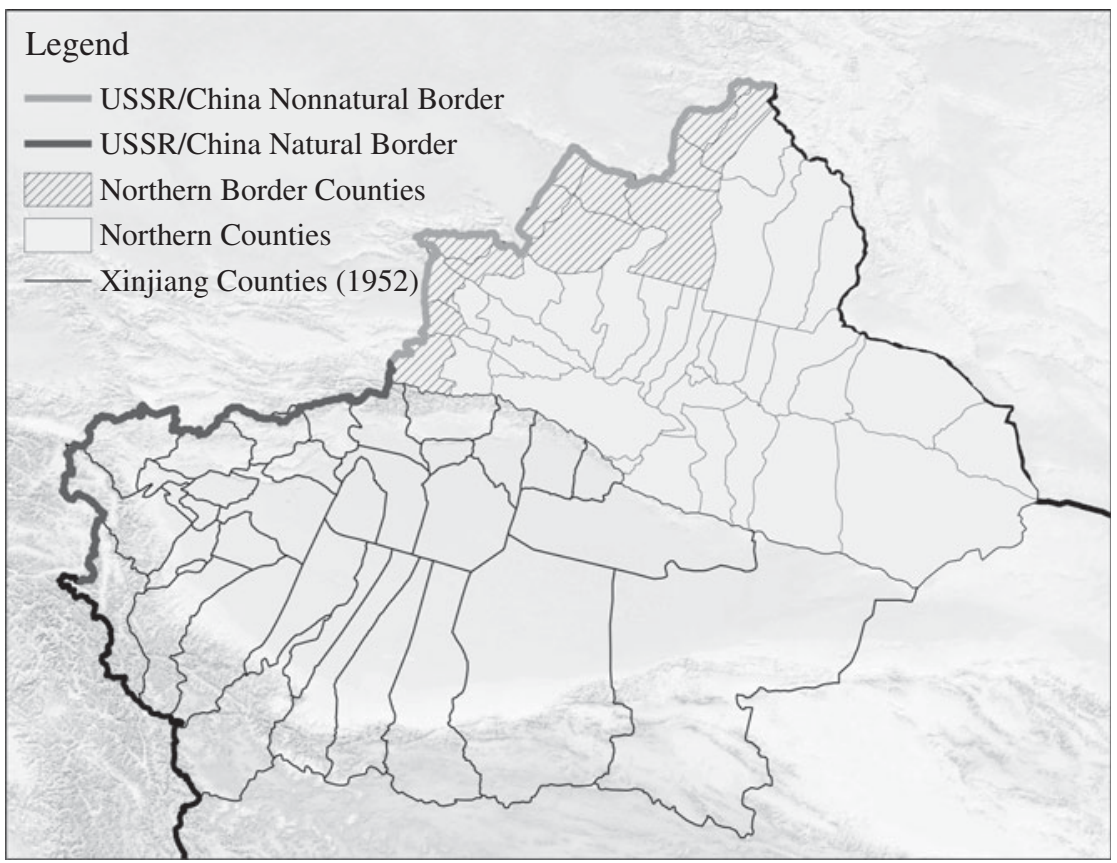

FIGURE 3. Xinjiang counties (1952) and measurement of proximity to a nonnatural border with the USSR

Finally, to test $\mathrm{H} 4$ we created a binary measure of whether a county had a formally contested border with the USSR. As Appendix A details, the overlapping territorial claims between the USSR and China along the Xinjiang border as of the 1950s largely stemmed from ambiguities and contradictions in past treaty texts and were thus a function of idiosyncratic geography — for example, ambiguity over the location of the major ridge of the Tian Shan or the lines connecting historic border posts. Appendix Figure 1A illustrates where these overlapping territorial claims were located in space.

\section{Empirics}

To test our hypotheses, we model the effect of changing geopolitical context on demographic change using a first-difference fixed effect difference-in-differences specification. Our effect of interest is the demographic effect of an area being on 
the border or having a greater fifth-column minority during a conflict. Although all areas in China and the USSR were threatened by the advent of the Sino-Soviet split and so experienced demographic change, we can use nonborder areas or those with fewer minority populations as plausible counterfactuals to identify the marginal effect of being on the border or having a greater fifth-column population during a conflict. It would, of course, be difficult to credibly identify this effect by comparing average differences across such areas. Even if we include year dummies and so pick up common temporal shocks such as generally higher migration during the years of the Great Leap Forward (1958-62) or the Cultural Revolution (1966-76), there is likely a substantial amount of unobserved spatial heterogeneity such as the presence of natural resources, territorial "homelands," low state capacity in mountainous areas, or quality of land that affects demographic change. If these unobserved factors also correlate with proximity to an international border or the presence of a particular minority, then our estimates of the effect of changing geopolitical context may be biased.

A major advantage of panel data over cross-sectional data is that we can difference out both common temporal shocks and this kind of time-invariant unobserved spatial heterogeneity. We do so by, in each period, analyzing the change in provincial or county demography. First differences and ordinary fixed effect estimation are very similar. The major distinction is that first differences are more efficient when there is serial correlation in the error term. The Wooldridge first-difference-based test indicates that there is serial correlation in the first derivative error term $(p$ value $<0.000)$ so we will employ first differences rather than fixed effects.

The identifying assumption is parallel trend. This means that we are assuming that, without the shock to geopolitical context brought about by the Sino-Soviet split, the change in migration or population from 1958 to 1959 or 1982 to 1983 would have been the same on average across provinces and counties bordering and not bordering the USSR. We will later verify this assumption by graphically illustrating the similar trend in migration to provinces bordering the USSR and not bordering the USSR pre-1959.

Finally, in all specifications, we conservatively cluster observations at the provincial and county levels using Arellano's covariance matrix ${ }^{71}$ to account both for general heteroskedasticity and serial cross-sectional correlation in the error term.

\section{Provincial-level Results}

We begin with the results of our provincial model specification, which provide the best-identified evidence in support of $\mathrm{H} 1$ due to the large number of pre-treatment periods. We find that the Sino-Soviet split is estimated to lead to an additional 6 to 15 percent increase in migration to each province bordering the USSR (Table 3, columns 1-4) and an overall increase of 340,000 people (columns 5-6). This is a 
very substantively significant increase given that the average population of the four border provinces was only 10 million in 1958. Table A.6 in the appendix reports the covariate coefficient estimates. As expected, higher levels of provincial GDP, lower death rates, and lower grain production growth per capita ${ }^{72}$ are associated with higher migration and population growth. All other covariates tend to be more mixed in sign or insignificant.

TABLE 3. Diff-in-diff: The effect of the Sino-Soviet split on demographics of border and nonborder provinces

\begin{tabular}{|c|c|c|c|c|c|c|}
\hline & \multicolumn{2}{|c|}{ Inward migration } & \multicolumn{2}{|c|}{ Net migration } & \multicolumn{2}{|c|}{ Population $(10,000)$} \\
\hline & (1) & (2) & (3) & (4) & (5) & (6) \\
\hline SINO-SOVIET SPLIT & $\begin{array}{l}0.07 * * * \\
(0.03)\end{array}$ & $\begin{array}{c}0.05^{*} \\
(0.03)\end{array}$ & $\begin{array}{c}0.02 \\
(0.02)\end{array}$ & $\begin{array}{c}0.03 \\
(0.02)\end{array}$ & $\begin{array}{l}-8.63 \\
(10.88)\end{array}$ & $\begin{array}{c}-14.16^{* *} \\
(6.32)\end{array}$ \\
\hline BORDER USSR:SINO-SOVIET SPLIT & $\begin{array}{l}0.14 * * * \\
(0.04)\end{array}$ & $\begin{array}{l}0.14 * * * \\
(0.04)\end{array}$ & $\begin{array}{l}0.06^{* *} \\
(0.03)\end{array}$ & $\begin{array}{l}0.11^{* *} \\
(0.05)\end{array}$ & $\begin{array}{l}35.01 * * * \\
(12.70)\end{array}$ & $\begin{array}{l}41.58^{* * * *} \\
(9.00)\end{array}$ \\
\hline First Differences & Yes & Yes & Yes & Yes & Yes & Yes \\
\hline Provincial Controls & No & Yes & No & Yes & No & Yes \\
\hline Provinces & 29 & 27 & 28 & 27 & 29 & 27 \\
\hline Observations & 910 & 782 & 896 & 782 & 903 & 782 \\
\hline F-statistic p-value & 0.00 & 0.00 & 0.02 & 0.03 & 0.01 & 0.00 \\
\hline
\end{tabular}

Notes: Each model is a provincial-level first-difference difference-in-differences specification where treatment of territorial threat is determined by the interaction between provincial contiguity with the USSR and the years of the Sino-Soviet split. Standard errors are clustered at the provincial level using Arellano's covariance matrix. F-statistic tests whether the effect of Sino-Soviet split is different across border/nonborder provinces. ${ }^{*} p<.10 ; * * p<.05 ; * * p<.01$.

The specifications when pooling across provinces are more mixed in terms of statistical significance but the reported effects also support H1 (Table A.9). We were concerned that these results may have been driven by a particular province. We thus ran the main model dropping Xinjiang, Jilin, Heilongjiang, and Inner Mongolia successively, and the results are unchanged (Table A.8, columns 2-5).

One may still be concerned about violation of the parallel trends assumption. To address this, we first ran the main model dropping all provinces except those contiguous with a province that is contiguous with the USSR (for an illustration see Figure 1). The results are unchanged-border provinces still had a disproportionate increase in migration and population as a result of the Sino-Soviet split compared to otherwise similar northern provinces (Table A.10). These results indicate that there was a disproportionate demographic effect of being on the USSR border during the Sino-Soviet split as opposed to a general northern China effect.

72. This result makes sense given the connection between exaggerated grain production growth and increased mortality during the Great Leap Forward. See Meng, Qian, and Yared 2015. 
Second, we applied the generalized synthetic control (GSC) method which is explicitly designed to deal with violation of parallel trend. ${ }^{73}$ The GSC method produces an unbiased estimator of the average treatment effect while relaxing the assumption that the average outcomes of treated and control units followed parallel trends. ${ }^{74}$ The essence of the GSC procedure is the construction of a more plausible counterfactual demographic trend for the border provinces from which we can then judge the effects of the Sino-Soviet split. ${ }^{75}$

The effects again support H1. The estimated effect of the Sino-Soviet split on migration and total population of the border provinces is significantly greater than in the first-difference results (Table A.7) with the Sino-Soviet split estimated to have increased the total population of the border provinces by 1.3 million people. The substantial effect of the Sino-Soviet split on the provinces bordering the USSR is also clear from Figures 4 and 5. The synthetic counterfactual and the border provinces had very similar trends in migration and population growth prior to 1959 , and the Sino-Soviet split clearly led to a significant increase in migration and population in the provinces bordering the USSR.

Finally, we can also test $\mathrm{H} 1$ in a different way by examining whether the provinces bordering the USSR experienced a disproportionate rise in the proportion of its population that is Han Chinese during the Sino-Soviet split. Although data on ethnic proportions are more scanty, we find indeed that there was an additional 37 to 42 percent rise in the percentage of Han in provinces bordering the USSR between 1953 and 1982 (Table A.11).

To rule out the increasing settlement of China's border provinces as simply a function of progressively increasing state capacity in the frontier over time, we can instead test whether there was a disproportionate drop in migration and population in the borderlands at the conclusion of the Sino-Soviet split in the 1980s. This is indeed the case - the border provinces experienced a disproportionate drop in population and inward migration after 1982 relative to the late 1960s and 70s (Supplementary Appendix B). Consistent with the importance of geopolitical context rather than progressively improving state capacity for incentivizing statesponsored demographic change in a frontier, this suggests that once the SinoSoviet split ended, mass Han settlement of the borderlands ceased. For example, while the proportion of non-Han in Xinjiang fell from 93 percent in 1953 to just over 59 percent by 1982, it began to rise once more to 62 percent by 1990 as mass Han settlement of Xinjiang ceased.

73. Xu 2017.

74. For discussion of the assumptions underlying the GSC method, see Xu 2017, 60-62.

75. Since gsynth requires a balanced panel, prior to running these models we interpolated a small amount of missing data using the Amelia II package. Honaker, King, and Blackwell 2011. For the missingness plot, see Supplementary Materials B. 


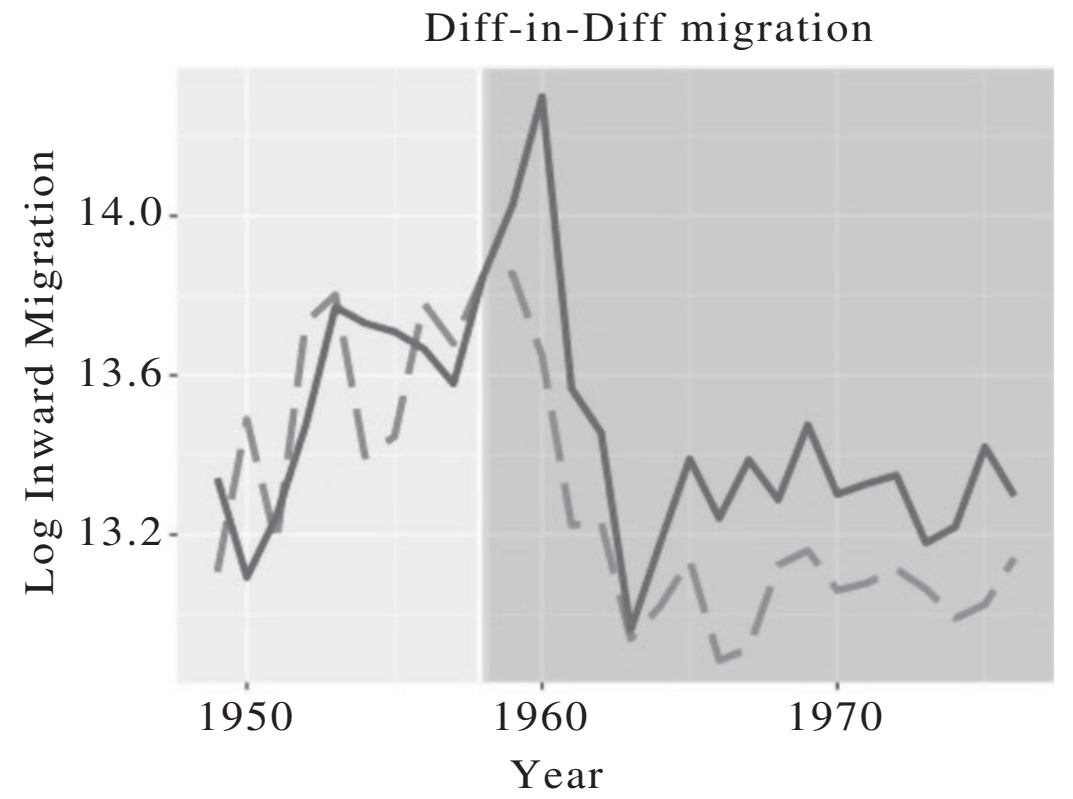

FIGURE 4. Comparison of log migration to the four border provinces (solid) and the counterfactual created from the composite synthetic control (dashed)

\section{Xinjiang County-level Results}

Regarding our more disaggregated predictions about the location and ethnicity-specific predictors of demographic engineering using county-level data from Xinjiang, the difference-in-differences results support hypothesis H2. The Sino-Soviet split is associated with an average fall of 108 Russians across every Xinjiang county, which constitutes an average 47 percent fall in the pre-split Russian population (Table 4). Moreover, consistent with our theory, only the ethnic Russian population significantly fell as a result of the Sino-Soviet split.

Also consistent with $\mathrm{H} 2$, state-sponsored bingtuan and Han resettlement was particularly targeted at those counties that held a significant ethnically Russian population (Table 5). For example, a county that had 100 more Russians than an otherwise similar county is expected to have a 10 percent greater increase in percentage Han during the Sino-Soviet split (column 4). Indeed, when examining the coefficient on POP. RUSSIAN, one can see that increases in bingtuan and Han settlement are associated with the location of ethnic Russians only during the years of the Sino-Soviet split.

Again, this effect is unique to the Russian minority; we do not obtain similar results when instead replacing population Russian with the population of a county that is 


\section{Diff-in-Diff migration}

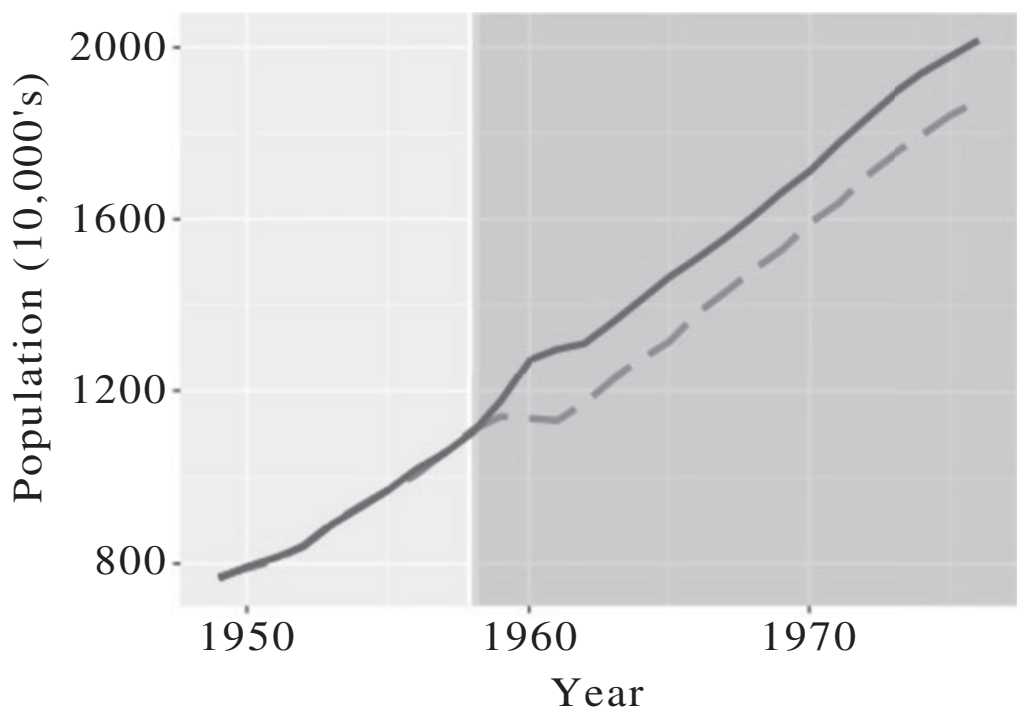

FIGURE 5. Comparison of total population of the four border provinces (solid) and the counterfactual created from the composite synthetic control (dashed)

Hui, Han, Kazakh, Kyrgyz, or Uyghur (Figures 6-7). ${ }^{76}$ Given the politically central role that Russians played in the former USSR, we interpret these results as suggesting that both ethnic cleansing and state-sponsored resettlement were targeted at an ethnic minority viewed as particularly close politically to the USSR.

Turning to the theorized heterogeneity across natural and nonnatural border areas, the difference-in-differences results are supportive of H3. The Sino-Soviet split led to a significant rise on average in both the number of XPCC (bingtuan) settlers and the proportion of Han Chinese across all counties in Xinjiang (Table 6). However, this rise was particularly dramatic in counties proximate to Xinjiang's nonnatural northern border with the USSR. Whether we measure proximity through a binary measure of a county being located in northern Xinjiang (columns 1 and 4), a binary measure of whether a county shares a nonnatural border with the USSR (columns 2 and 5), or simply through the distance of each county to Xinjiang's northern border with the USSR (columns 3 and 6), Han and bingtuan settlement was particularly targeted at those counties proximate to Xinjiang's nonnatural border with the USSR. When instead pooling across all counties in all years, the results are unchanged (Table A.12). 
TABLE 4. Diff-in-diff: The effect of the Sino-Soviet split on ethnic populations across Xinjiang counties 1952-1985

\begin{tabular}{lllllll}
\hline & \multicolumn{5}{c}{ Population by Ethnicity } \\
\cline { 2 - 7 } & \multicolumn{1}{c}{ Russian } & Han & Hui & Kyrgyz & Kazakh & Uyghur \\
\hline \multirow{2}{*}{ SINO-SOVIET SPLIT } & $-107.77 * * *$ & $9,899.93 * * *$ & $703.73^{* * *}$ & -6.62 & 62.66 & $1,970.51$ \\
& $(37.23)$ & $(2,180.00)$ & $(147.02)$ & $(97.17)$ & $(312.46)$ & $(1,282.01)$ \\
First Differences & Yes & Yes & Yes & Yes & Yes & Yes \\
Counties & 80 & 80 & 80 & 80 & 80 & 80 \\
Observations & 1896 & 1896 & 1896 & 1896 & 1896 & 1896 \\
\hline
\end{tabular}

Notes: Each model is a first-difference difference-in-differences specification where the DV is the ethnic population of each Xinjiang county between 1952 and 1985. Standard errors are clustered at the county level using Arellano's covariance matrix. $* p<.10 ; * * p<.05 ; * * * p<.01$.

In general, in counties where the USSR's threat to territorial control was most acute, the rise in bingtuan settler population and the proportion of Han was almost double that of other counties in Xinjiang. For example, while the Sino-Soviet split led to an approximately 7 percent rise in the proportion of Han across Xinjiang, it led to a doubly significant 14 percent rise in the counties of Xinjiang that shared a nonnatural border with the USSR (column 5). As one progressively moves further away from Xinjiang's nonmountainous border with the USSR, the rise in county XPCC and Han settlement during the Sino-Soviet split is gradually attenuated (columns 3 and 6).

Also consistent with $\mathrm{H} 3$, the rise of Han demographic dominance in the counties sharing a nonnatural border with the USSR was achieved not only through an influx of new XPCC settlers; it was also achieved via the expulsion of the ethnically Russian community in the borderlands (Table 7). The reduction in Russian population is particularly dramatic in the counties in northern Xinjiang (column 1) and the counties of Xinjiang that shared a nonnatural border with the USSR (column 3). Similarly, the fall in the Russian population during the Sino-Soviet split is most dramatic in the counties sharing a nonnatural border with the USSR. As one progressively moves away from Xinjiang's northern border, there is correspondingly a less dramatic fall in the Russian population (column 5). The Sino-Soviet split is estimated to lead to a fall of approximately 200 ethnic Russians in Xinjiang counties proximate to a nonnatural border with the USSR, which amounts to an average 48 percent decline in the Russian population. ${ }^{77}$ The estimated results when pooling across counties are generally similar.

These results are not being driven by our dichotomous measure of natural and nonnatural borders. Because the difficulty of crossing a border is continuous, we can 
instead measure the "naturalness" of a border through a more continuous measure of the mean altitude of each county. The difference-in-difference results are supportive of hypothesis 3. In counties of Xinjiang where mean altitude is lower, there was a substantially greater fall in the ethnic Russian community and increase in Han and bingtuan populations during the Sino-Soviet split (Supplementary Appendix B).

TABLE 5. Diff in diff: The effect of the Sino-Soviet split on XPCC (bingtuan) and \% Han in counties by population Russian 1952-1985

\begin{tabular}{|c|c|c|c|c|}
\hline & \multicolumn{2}{|c|}{ Log Pop XPCC } & \multicolumn{2}{|c|}{ Log Han \% } \\
\hline & (1) & (2) & (3) & (4) \\
\hline POP. RUSSIAN & $\begin{array}{c}-0.002 * * * * \\
(0.001)\end{array}$ & $\begin{array}{c}-0.001 * * * \\
(0.0004)\end{array}$ & $\begin{array}{c}-0.0001 * \\
(0.0000)\end{array}$ & $\begin{array}{c}-0.0000 \\
(0.0000)\end{array}$ \\
\hline SINO-SOVIET SPLIT & $\begin{array}{l}3.06 * * * \\
(0.27)\end{array}$ & $\begin{array}{l}3.63 * * * \\
(0.30)\end{array}$ & $\begin{array}{l}0.08 * * * \\
(0.01)\end{array}$ & $\begin{array}{l}0.04 * * * \\
(0.01)\end{array}$ \\
\hline POP. RUSSIAN: SINO-SOVIET SPLIT & $\begin{array}{l}0.01 * * * * \\
(0.002)\end{array}$ & $\begin{array}{l}0.02 * * \\
(0.01)\end{array}$ & $\begin{array}{c}0.0000 \\
(0.0000)\end{array}$ & $\begin{array}{l}0.001 * * * \\
(0.0003)\end{array}$ \\
\hline First differences & Yes & No & Yes & No \\
\hline Counties & 80 & 80 & 80 & 80 \\
\hline Observations & 1175 & 1175 & 1896 & 1896 \\
\hline F-statistic & 0.00 & 0.02 & 0.93 & 0.01 \\
\hline
\end{tabular}

Notes: Each model is a difference-in-differences specification where the DV is the log of Xinjiang county XPCC (bingtuan) population or the log percentage of the county that is Han between 1952 and 1985. Standard errors are clustered at the county level using Arellano's covariance matrix. F-statistic tests whether the effect of Sino-Soviet split is different across counties by population. ${ }^{*} p<.10 ; * * p<.05 ; * * p<.01$.

Again, the fall in population is unique to China's Russian minority-there is no similar reduction in the nonnatural border counties among Xinjiang's much larger Hui, Kyrgyz, Kazakh, or Uyghur minorities. ${ }^{78}$ These results therefore run contrary to past predictions that the Sino-Soviet split led to exclusionary measures directed toward China's Kazakh and Uyghur minorities. ${ }^{79}$ Although the Sino-Soviet split did lead to measures designed to cut off Kazakhs and Uyghurs from their crossborder kin, this did not take the form of expulsions or resettlement. For example, during the 1962 Yili-Tacheng Incident approximately 75,000 ethnic Kazakhs and Uyghurs looted Chinese government buildings and fled across the border to the USSR with their contraband and livestock. ${ }^{80}$ The Chinese state was dismayed at the Kazakh exodus and sought to prevent any more Kazakhs and Uyghurs leaving for the USSR by sealing the border and retrieving information on those who left from Soviet officials. Given that the state sought to prevent their exodus, this suggests that non-Russian minorities were not viewed as fifth columns.

78. See Supplementary Materials B.

79. Han and Mylonas 2014; Mylonas 2012.

80. Zhang 2011. 


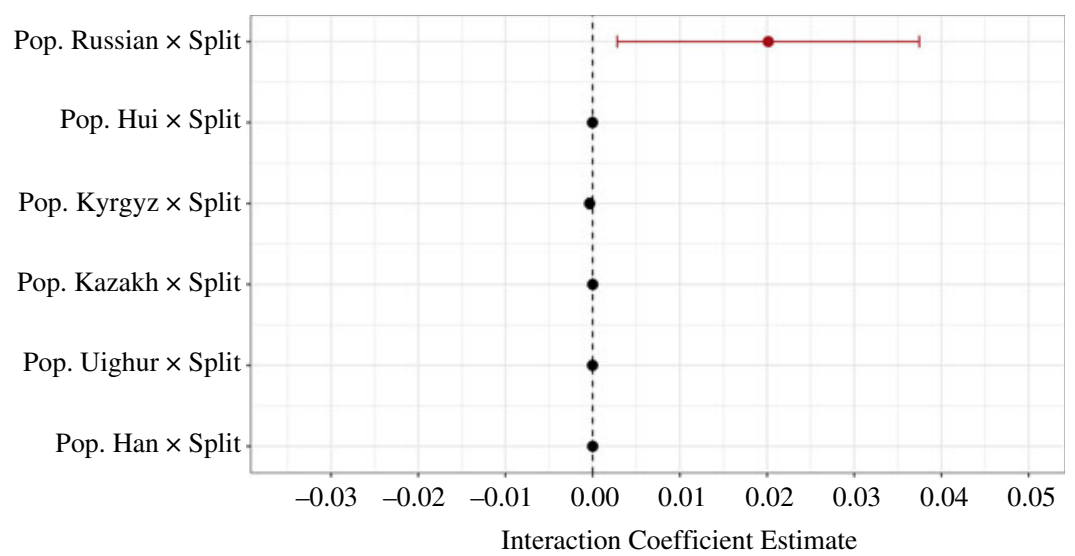

FIGURE 6. Effect of Sino-Soviet split on log bingtuan population by ethnic population with $95 \%$ confidence intervals

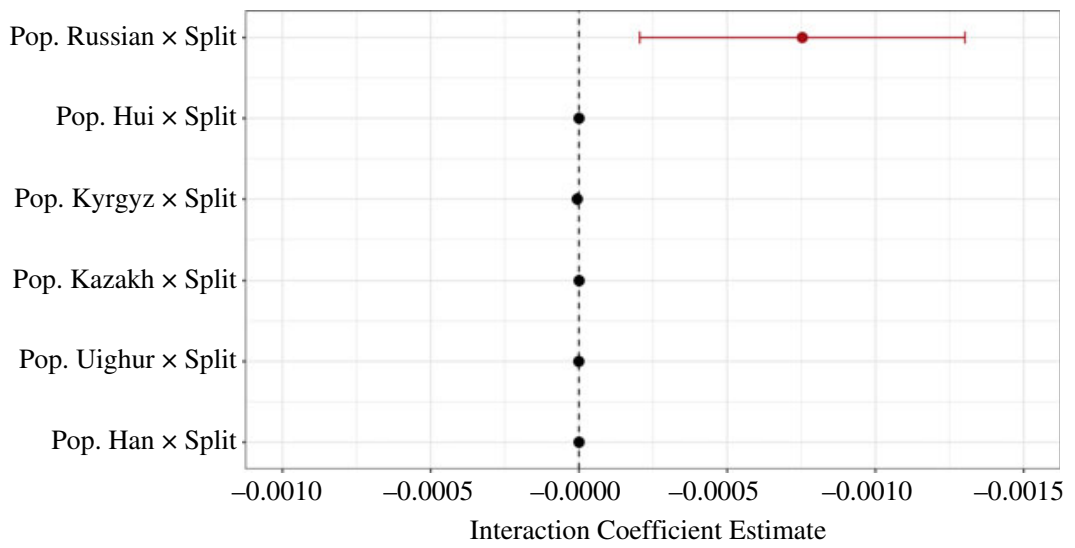

FIGURE 7. Effect of Sino-Soviet split on log Han percent by ethnic population with 95\% confidence intervals

Given the politically central role that Russians played in the former USSR ${ }^{81}$ we interpret the unique fall in the ethnic Russian community as suggesting that exclusion was focused on China's relatively small but politically influential Russian minority who were disproportionately induced to leave for the USSR as a result of the SinoSoviet split. More broadly, the fact that demographic engineering was targeted at 
partitioned Russians rather than Kazakhs or Uyghurs suggests that having crossborder kin in a hostile foreign power is not enough to produce demographic engineering; it is also essential that such kin be in a position of power in the foreign state. We have substantiated this interpretation through off-record discussions with bingtuan members in the Fourth Bingtuan Division in the Yili Prefecture. ${ }^{82}$ In essence, the synchronous expulsion of ethnic Russians and an influx of state-sponsored Han settlers led to rapid demographic change in areas of Xinjiang proximate to a nonnatural border with the USSR.

TABLE 6. Diff-in-diff: The effect of the Sino-Soviet split on XPCC (bingtuan) settler population and \% Han in Xinjiang counties by border distance 1952-1985

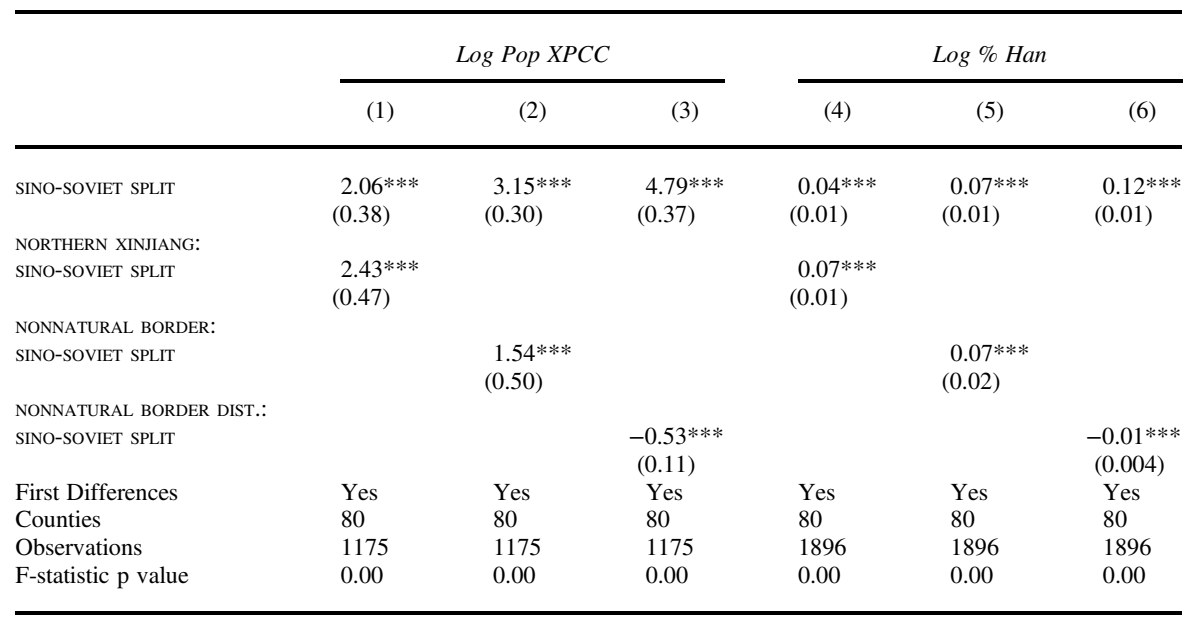

Notes: Each model is a first-difference difference-in-differences specification where the DV is the log of Xinjiang county XPCC (bingtuan) population or the percentage of the county that is Han between 1952 and 1985. Standard errors are clustered at the county level using Arellano's covariance matrix. F-statistic tests whether the effect of Sino-Soviet split is different across nonnatural border and other counties. $* p<.10 ; * *<<.05 ; * * * p<.01$.

Finally, inconsistent with H4, there is no significant difference in XPCC and Han settlement across counties that shared a formally disputed border with the USSR relative to other counties (Table A.13). Moreover, counties closer to disputed territories in Xinjiang did not experience significantly greater resettlement during the SinoSoviet split relative to either other counties or to themselves outside the split (Supplementary Materials B). In this respect, the results suggest that Chinese efforts at demographic engineering were not undertaken with a view to consolidating formally disputed territory. Rather, China's general fear was that a secessionist crossborder insurgency could destabilize its hold over Xinjiang as a whole. The evidence

82. Because of the extreme sensitivity of this topic and repressive context, we cannot provide quotes. 
TABLE 7. Expulsions: The effect of the Sino-Soviet split on the Russian population in Xinjiang counties by border distance 1952-1985

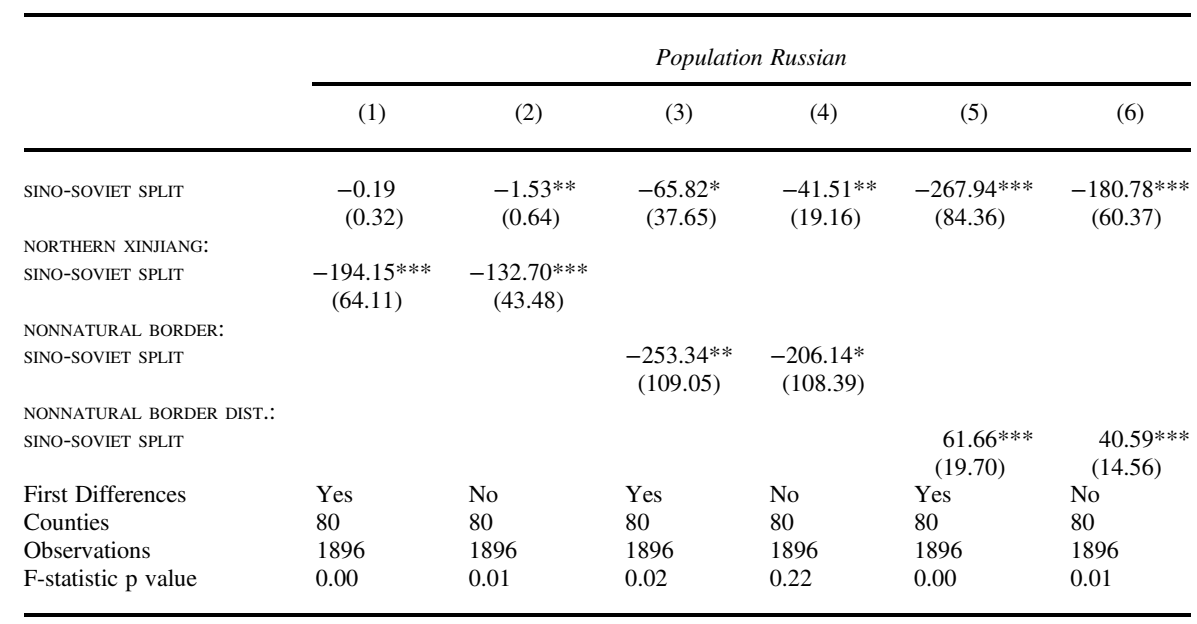

Notes: Each model is a difference-in-differences specification where the DV is the total population of Russians in each Xinjiang county. Standard errors are clustered at the county level using Arellano's covariance matrix. F-statistic tests whether the fall in ethnic Russians over the Sino-Soviet split is different across nonnatural border and other counties. $* p$ $<.10 ; * * p<.05 ; * * * p<.01$.

thus suggests that demographic engineering was undertaken to consolidate Chinese control over areas of Xinjiang characterized by nonnatural and permeable borders and illicit personnel, equipment, and propaganda flows from the USSR.

\section{Soviet Response}

Here we test whether the Soviet Union similarly sought to consolidate its control over its frontier with China by engaging in demographic engineering. We test only hypotheses $\mathrm{H} 1$ and $\mathrm{H} 2$ because of a lack of disaggregated data on demographic change across natural and nonnatural border areas. Nevertheless, patterns of demographic change in the former Soviet Union indeed suggest that the Sino-Soviet split analogously induced (1) the mass resettlement of ethnic Russians and cleansing of Chinese on the Russian side of the Sino-Soviet border and (2) the resettlement of Russians to Chinese-populated areas.

Czarist Russia had long incentivized the resettlement of Russians to its newly acquired territories in the Far East and, under Stalin, the USSR frequently used forced deportations to populate and develop Siberia. This resettlement policy experienced new life as a result of the downturn in Sino-Soviet relations. As An summarizes, "by the mid-1960s, the Soviet Union was displaying conspicuous haste in planning to develop the vast and thinly populated region of Siberia by pouring in 
substantial capital and people. This policy indicated the USSR's long-term goal to turn Siberia into a bastion against the Chinese, and had made feverish efforts to attract permanent settlers." "83 The Sino-Soviet split also led to the mass expulsions of ethnic Chinese in Russia. The Russian Empire had long feared that China could use its large population and influence over the expatriate Chinese community to undermine its control over its newly acquired territories in the Far East. Following the decline in Sino-Soviet relations in 1959, the Soviet Union again deported a substantial component of the ethnic Chinese community who had migrated to the USSR to study and conduct shuttle trade in the Far East over the preceding decade. ${ }^{84}$

This theorized decline in the ethnic Chinese community and increase in the ethnic Russian community in the Russian Far East can be tested using Soviet demographic statistics. Unfortunately, unlike in China, no publicly available yearly demographic data exist for the USSR. However, disaggregated oblast-level demographic data exist for five censuses for the Russian Soviet Federative Socialist Republic between 1939 and $1989 .{ }^{85} \mathrm{We}$ can therefore test using an analogous difference-in-differences design whether the censuses conducted during the Sino-Soviet split (19591982) report a disproportionate decline in the ethnically Chinese community and rise in the ethnically Russian community in the four Russian oblasts in the Far East bordering China (see Figure 8).

This is indeed the case. Consistent with H1, the Sino-Soviet split is estimated to have led to an increase of approximately 157,000 to 240,000 ethnic Russians in each of the Far East Russian oblasts bordering China (Table 8, columns 1 and 2) and a total increase in population of between 156,000 and 274,000 (columns 5 and 6). Moreover, the Sino-Soviet split is associated with a fall of approximately 1,000 in the total ethnic Chinese population in the four border oblasts, which constitutes an average 35 percent decline in the Chinese population. The approximately identical estimate of both total population and ethnic Russian change suggests that the increase in the Russian population is the product of internal migration rather than ethnic switching among USSR nationals. ${ }^{86}$ Also consistent with $\mathrm{H} 2$, the results suggest that ethnic Russian resettlement was targeted at areas populated by more Chinese during the Sino-Soviet split. Despite the fact that statistical significance varies across specifications, areas populated by more Chinese are estimated to have less

\section{An $1973,87$.}

84. Lüthi 2010.

85. Oblast-level demographic data do not exist for the Central Asian republics so they are excluded from the analysis. The available years with standard oblast boundaries are 1939, 1959, 1970, 1979, and 1989. Data source is Russian State Archive of Economy, retrieved from <http://www.demoscope.ru/weekly/ ssp/census.php?cy=2> on 12 February 2017.

86. It could also be the increase in total population is caused by more individuals in the Far East declaring themselves USSR citizens. However, the increase in the ethnic Russian population in the Far East due to the Sino-Soviet split is less plausibly the result of more individuals declaring themselves USSR nationals than, for example, an increase in the Chinese or Korean population would have been. Indeed, we find that the Chinese population fell over the split. As such, the increase in the ethnic Russian population is strongly suggestive of a mechanical increase in the Far East Russian population as a result of internal colonization rather than more individuals declaring themselves nationals. 
Russian population growth outside the Sino-Soviet split relative to other areas and greater Russian population growth during the split (Table A.14).

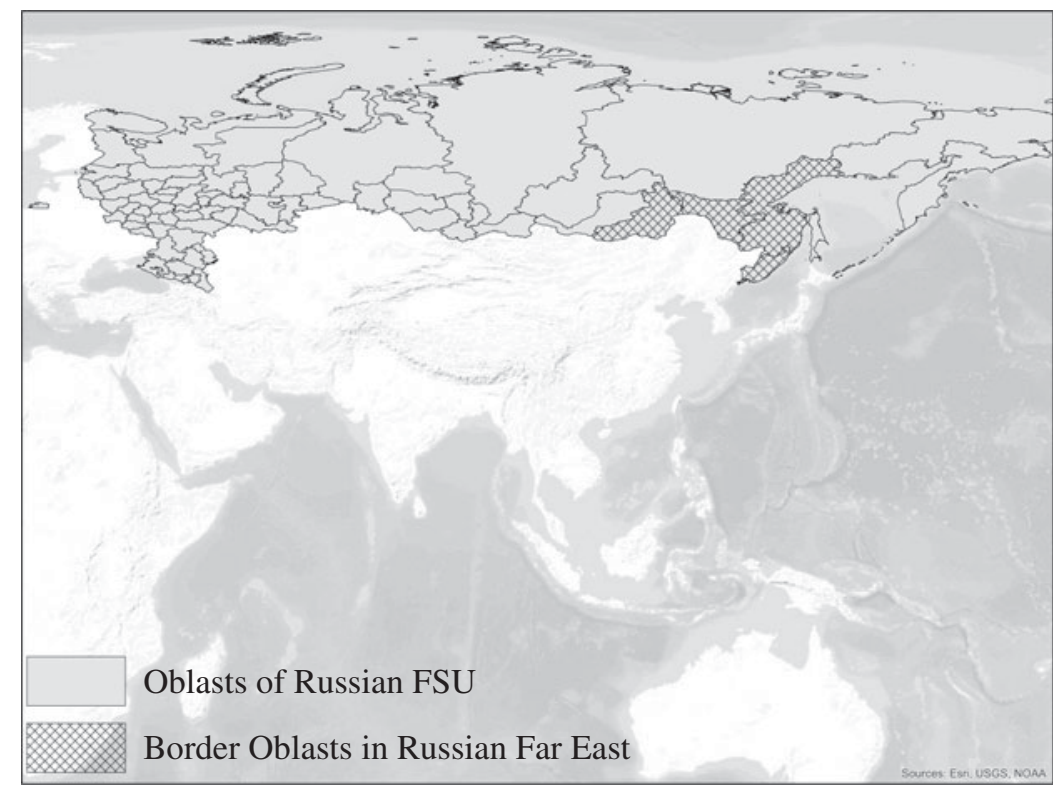

FIGURE 8. Oblasts of the Russian Soviet Federative Socialist Republic of the former Soviet Union (FSU)

Given the long time period between each Russian census and the lack of oblastlevel census data from the other Soviet republics, however, we acknowledge that we cannot definitively conclude that these demographic shifts on the Russian frontier can be attributed to the changing nature of Sino-Soviet relations. Nevertheless, the strikingly parallel nature of state-sponsored demographic change on either side of the Sino-Soviet border from 1959 to 1982 suggests that the theory outlined here accurately captures the dynamics of demographic engineering.

\section{Conclusion}

We theorized that states employ demographic engineering to forestall secessionist minority mobilization and cross-border insurgencies. As such, we predicted that demographic engineering would be targeted in conflicts at vulnerable nonnatural border zones and those populated by minorities who are co-ethnics with elites in a hostile foreign power. We then tested our theoretical predictions against the timing and location of demographic engineering in China and the USSR during the Cold 
War. Exploiting the temporal break in relations between China and the USSR during the Sino-Soviet split (1959-1982) and cleanly identifying its effects via a differencein-differences design, we found that Han settlement during the Sino-Soviet split was particularly targeted at Chinese border areas with the USSR lacking a natural boundary and populated by ethnic Russians. We found evidence that mass expulsions were directed at China's Russian minority who resided in areas proximate to a nonnatural boundary with the USSR. These results suggest that as China and the USSR fell out politically in the late 1950s and the USSR sought to undermine Chinese control over its frontier, China responded by expelling ethnic Russians and fostering mass Han settlement to areas where its territorial control was most vulnerable. Correspondingly, the USSR in turn expelled ethnic Chinese and fostered mass Russian settlement to its vulnerable Far East frontier with China.

TABLE 8. Russia: The effect of the Sino-Soviet split on the demographics of Russian oblasts by contiguity with China 1939-1989

\begin{tabular}{|c|c|c|c|c|c|c|}
\hline & \multicolumn{2}{|c|}{ Russian population } & \multicolumn{2}{|c|}{ Chinese population } & \multicolumn{2}{|c|}{ Total population } \\
\hline & (1) & (2) & (3) & (4) & (5) & (6) \\
\hline SINO-SOVIET SPLIT & $\begin{array}{c}-114,953 * * * \\
(40,447)\end{array}$ & $\begin{array}{c}-190,907 * * * \\
(50,853)\end{array}$ & $\begin{array}{r}35 \\
(28)\end{array}$ & $\begin{array}{r}23 \\
(27)\end{array}$ & $\begin{array}{l}-141,101 * * * \\
(44,637)\end{array}$ & $\begin{array}{c}-248,855^{* * * *} \\
(55,242)\end{array}$ \\
\hline $\begin{array}{l}\text { BORDER CHINA: } \\
\text { SINO-SOVIET SPLIT }\end{array}$ & $\begin{array}{c}162,598 * * * \\
(56,820)\end{array}$ & $\begin{array}{c}243,112 * * * \\
(65,365)\end{array}$ & $\begin{array}{l}-950 * * \\
(463)\end{array}$ & $\begin{array}{l}-967 * * \\
(476)\end{array}$ & $\begin{array}{l}165,426 * * \\
(64,071)\end{array}$ & $\begin{array}{c}274,457 * * * \\
(71,862)\end{array}$ \\
\hline $\begin{array}{l}\text { First differences } \\
\text { Oblasts } \\
\text { Observations } \\
\text { F-statistic p value }\end{array}$ & $\begin{array}{l}\text { Yes } \\
77 \\
356 \\
0.01\end{array}$ & $\begin{array}{l}\text { No } \\
77 \\
356 \\
0.06\end{array}$ & $\begin{array}{l}\text { Yes } \\
77 \\
298 \\
0.04\end{array}$ & $\begin{array}{l}\text { No } \\
77 \\
298 \\
0.00\end{array}$ & $\begin{array}{l}\text { Yes } \\
77 \\
356 \\
0.02\end{array}$ & $\begin{array}{l}\text { No } \\
77 \\
356 \\
0.03\end{array}$ \\
\hline
\end{tabular}

Notes: Each model is a difference-in-differences specification where the unit of analysis is the Russian oblast in the former Soviet Union and the DV is demographic change as measured in five Soviet censuses (1939-1989). Standard errors are clustered at the county level using Arellano's covariance matrix. F-stat tests whether population change in the Sino-Soviet split is different across border/nonborder oblasts. * $p<.10 ; * * p<.05 ; * * * p<.01$.

One may question the extent to which our results are generalizable to other settings. China and the former USSR during the Cold War both exercised a degree of control over their internal demography that is incomparable to non-Communist countries. Demographic engineering in market-based economies such as twentieth-century Italy tends to take place not through the wholesale coercive movement of people but rather through government investment to economically incentivize individuals from the core to move to contested peripheries. Although future work would do well to explore the different means through which states have sought to alter their internal demography and their potentially different political consequences, we contend that the scope conditions that incentivized demographic engineering in China and the 
former USSR are generalizable and useful for understanding the incidence of statesponsored demographic change elsewhere. Chiefly, both China and the former USSR during the twentieth century were states characterized by a majority ethnic group inhabiting a core region and ethnically distinct peripheries. Both countries were also located in a regional system in which international borders were highly contested and dynamic. These shared structural similarities help explain why other states in Asia over the same time period-whether Afghanistan, Burma, Bangladesh, Bhutan, Indonesia, Iraq, India, Israel, Thailand, or Sri Lanka-provided material inducements for individuals to resettle to contested border regions when the extent of demographic engineering in other parts of the world was more limited. When examining the history of highly consolidated states such as the United States, Canada, Japan, Italy, or the United Kingdom, we see that demographic engineering was also disproportionately undertaken during their periods of state expansion into ethnically distinct frontiers and competition with neighboring powers. We therefore expect our results to be generalizable not to all states at all periods of time but rather specifically to those engaged in processes of state building in ethnically distinct frontiers and contestation with neighboring powers.

Insofar as we have substantiated the critical international dimension to state-sponsored demographic change, our study's policy implications are clear. For example, in contemporary Burma or China, international actors and nongovernmental organizations have sought to limit demographic engineering against minorities by criticizing and slapping sanctions on domestic political leaders for violating human rights. But sanctions fail to acknowledge or address the structural factors producing state-sponsored demographic change in Rakhine state and Xinjiang, both of which are currently characterized by a cross-border insurgency. Our results suggest that efforts by concerned actors seeking to prevent demographic engineering would be best supplemented and/or redirected toward increasing the capacity and willingness of regional actors such as Afghanistan and Bangladesh to credibly commit to not providing a base for insurgent groups.

There is great scope for further work to better understand the conditions under which demographic engineering is employed by states and identify its likely international and domestic political consequences. It is far from the case that all instances of state-sponsored demographic change are related to international conflict. Future work would therefore do well to develop and test a domestic political rationale for when and where states would seek to coercively alter their internal demography. Such work would assist this paper in revitalizing the study of political demographyan academic subfield that Teiltelbaum notes has, despite periodic edited volumes, ${ }^{87}$ been largely neglected by social scientists. ${ }^{88}$ Because they focus on the developed world, demographers have tended to ignore the role of the state in structuring internal

87. For example, Goldstone, Kaufmann, and Toft 2012; Haklai and Loizides 2015; Weiner and Russell 2001.

88. Teitelbaum 2015. 
migration. ${ }^{89}$ Yet, rather than being being treated as only an input, ethno-national demography should be recognized and studied as a substantively important output of international relations. ${ }^{90}$ By theorizing and empirically testing predictors of state-sponsored demographic change, we seek to both bring the state back into the study of demography and bring political demography back into the purview of mainstream political science.

Allowing for a two-way relationship between international relations and domestic demographic change both complements and complicates the existing literature linking ethnic demography to outcomes such as the diffusion of conflict or to the formation of national borders. Of course, no scholar would disagree that the distribution of ethnic groups is the product of a complex, endogenous process of state building. Yet, it has been less well-recognized in precisely what way the endogeneity of ethnicity may confound empirical findings. Two key takeaways from the literature on ethnicity and conflict are (1) that more consolidated ethnic groups are more likely to engage in conflict $^{91}$ and (2) that conflict diffuses across partitioned ethnic groups. ${ }^{92}$ However, our findings show that both the concentration of minority ethnic groups and the existence of partitioned ethnic groups are a function of the incidence of historical conflict and the success or failure of state efforts at demographic engineering. Given the likelihood that existing findings using ethnic demography as an independent variable are therefore confounded in part by omitted variables, our results caution against the current tendency in quantitative work to implicitly treat the distribution of ethnic groups as exogenous. There is thus great scope for further work that can allow us to better understand the multifaceted relationship between international conflict, demographic change, and the formation of state boundaries.

Ideally, such work would help redress some of the limitations of this study. Our empirics have been oriented toward providing well-identified subnational evidence substantiating our core theoretical predictions. However, there remains great scope for cross-national research testing whether international conflict is indeed associated with ethnic homogenization in frontier zones and disproportionately so along nonnatural borders. There is also scope for future work to more closely attend to the strategic and plausibly dialectic nature of demographic engineering. For example, given a less dramatic and sudden worsening of ties, there may have been tit-for-tat expulsions and tit-for-tat resettlement of co-nationals to Sino-Soviet border areas. Further work on strategic interactions in demographic engineering therefore holds great promise.

Finally, there is great scope to integrate demographic engineering with other work on state building, conflict, and ethnicity and in so doing better understand its contribution to overall demographic change. Demographic engineering, though important, is but one of a basket of state-building strategies shaped by conflict. Future work on

89. Fan 2007

90. See Bulutgil 2016; Darden and Mylonas 2016; Hägerdal 2017; McNamee 2018.

91. See Cornell 2002; Horowitz 1985; Morelli and Rohner 2015; Toft 2003; Weidmann 2009.

92. See Buhaug and Gleditsch 2008; Cederman, Buhaug, and Rød 2009; Cederman, Girardin, and Gleditsch 2009; Salehyan 2009. 
state building would do well to theorize the relationship between war, state weakness in threatened peripheries, and the choice to respond with particular state-building strategies over others. Although our results measuring the impact of international conflict on internal migration and population are not confounded by the endogeneity of ethnicity, ethnic identity is also shaped by conflict and state building. For example, just drawing international borders can change individual identity as individuals seek to distinguish themselves from non-nationals. ${ }^{93}$ International conflict can also engender national homogenization by increasing patriotism, ${ }^{94}$ incentivizing the extension of state education, ${ }^{95}$ and incentivizing individual switching when, to avoid ethnic cleansing, members of vulnerable minorities may seek to "pass" as a member of another group. Territorial changes can exacerbate these shifts by incentivizing both ethnic cleansing of beached minorities ${ }^{96}$ and switches in ethnic identity driven by an altered demographic context. ${ }^{97}$

We suggest that key to systematizing this diffuse and nascent literature in political demography is collecting individual panel data that can test the conditions under which states shape both mechanical population movements and individual ethnic identity and, thus, disentangle their respective contributions to wider demographic change. For example, both widespread passing among beached minorities and demographic engineering can engender ethno-national homogenization along state borders, yet we have surprisingly little empirical understanding of the role that each has played in calcifying border delimitations over time. Endogenizing ethnicity to international relations therefore does not merely complicate the relationship among ethnicity, state building, and the diffusion of conflict; it also opens up fruitful avenues for future research.

\section{Supplementary Material}

Supplementary material for this article is available at <https://doi.org/10.1017/ S0020818319000067>.

\section{References}

An, Tai-sung. 1973. The Sino-Soviet Territorial Dispute. Philadelphia, PA: The Westminster Press. Arellano, Manuel. 1987. Computing Robust Standard Errors for Within-groups Estimators. Oxford Bulletin of Economics and Statistics 49 (4):431-34.

Balcells, Laia, and Abbey Steele. 2016. Warfare, Political Identities, and Displacement in Spain and Colombia. Political Geography 51:15-29.

93. Sahlins 1989.

94. Sambanis, Skaperdas, and Wohlforth 2015.

95. Darden and Mylonas 2016.

96. Bulutgil 2016.

97. See Laitin 1998; Posner 2005. 
Banister, Judith. 1991. China's Changing Population. Stanford, CA: Stanford University Press.

. 2001. Impacts of Migration to China's Border Regions. In Demography and National Security, edited by Myron Weiner and Sharon Stanton Russell, 256-302. New York: Berghahn Books.

Blaydes, Lisa. 2018. State of Repression: Iraq Under Saddam Hussein. Princeton, NJ: Princeton University Press.

Bleuer, Christian. 2012. State-building, Migration and Economic Development on the Frontiers of Northern Afghanistan and Southern Tajikistan. Journal of Eurasian Studies 3 (1):69-79.

Bookman, Milica Zarkovic. 1997. The Demographic Struggle for Power: The Political Economy of Demographic Engineering in the Modern World. Abingdon, UK: Taylor and Francis.

Buhaug, Halvard, and Kristian Skrede Gleditsch. 2008. Contagion or Confusion? Why Conflicts Cluster in Space. International Studies Quarterly 52 (2):215-33.

Bulutgil, H. Zeynep. 2016. The Roots of Ethnic Cleansing in Europe. Cambridge, UK: Cambridge University Press.

Carter, David B. 2010. The Strategy of Territorial Conflict. American Journal of Political Science 54 (4): 969-87.

Carter, David B., and Paul Poast. 2015. Why Do States Build Walls? Political Economy, Security, and Border Stability. Journal of Conflict Resolution 61 (2):239-70.

Cederman, Lars-Erik, Halvard Buhaug, and Jan Ketil Rød. 2009. Ethno-nationalist Dyads and Civil War: A GIS Based Analysis. Journal of Conflict Resolution 53 (4):496-525.

Cederman, Lars-Erik, Luc Girardin, and Kristian Skrede Gleditsch. 2009. Ethnonationalist Triads Assessing the Influence of Kin Groups on Civil Wars. World Politics 61 (3):403-37.

Chen, Jian. 2006. The Tibetan Rebellion of 1959 and China's Changing Relations with India and the Soviet Union. Journal of Cold War Studies 8 (3):54-101.

-2010. Mao's China and the Cold War. Chapel Hill, NC: University of North Carolina Press.

Cornell, Svante E. 2002. Autonomy As a Source of Conflict: Caucasian Conflicts in Theoretical Perspective. World Politics 54 (2):245-76.

Darden, Keith, and Harris Mylonas. 2016. Threats to Territorial Integrity, National Mass Schooling, and Linguistic Commonality. Comparative Political Studies 49 (11):1446-79.

Downes, Alexander B. 2008. Targeting Civilians in War. Ithaca, NY: Cornell University Press.

Fall, Juliet J. 2010. Artificial States? On the Enduring Geographical Myth of Natural Borders. Political Geography 29 (3):140-47.

Fan, C. Cindy. 2007. China on the Move: Migration, the State, and the Household. New York: Routledge. Fearon, James D., and David D. Laitin. 2011. Sons of the Soil, Migrants, and Civil War. World Development 39 (2):199-211.

Fravel, M. Taylor. 2008. Strong Borders, Secure Nation : Cooperation and Conflict in China's Territorial Disputes. Princeton, NJ: Princeton University Press.

Ginsburgs, George. 1978. The Sino-Soviet Territorial Dispute, 1949-64. New York: Praeger.

Gleditsch, Kristian Skrede, Idean Salehyan, and Kenneth Schultz. 2008. Fighting at Home, Fighting Abroad: How Civil Wars Lead to Interstate Disputes. Journal of Conflict Resolution 52 (4):479-506.

Goemans, H.E., and Kenneth A. Schultz. 2016. The Politics of Territorial Disputes: A Geospatial Approach Applied to Africa. International Organization 71 (1):31-64.

Goemans, Hein. 2006. Bounded Communities: Territoriality, Territorial Attachment, and Conflict. In Territoriality and Conflict in an Era of Globalization, edited by Miles Kahler and Barbara F. Walter, 25-61. New York: Cambridge University Press.

Goldstone, Jack A., Eric P. Kaufmann, and Monica Duffy Toft. 2012. Political Demography: How Population Changes Are Reshaping International Security and National Politics. Boulder, CO: Paradigm. Greenhill, Kelly M. 2008. Strategic Engineered Migration as a Weapon of War. Civil Wars 10 (1):6-21. Hägerdal, Nils. 2017. Ethnic Cleansing and the Politics of Restraint: Violence and Coexistence in the Lebanese Civil War. Journal of Conflict Resolution 63 (1):59-84.

Haklai, Oded, and Neophytos Loizides. 2015. Settlers and Conflict Over Contested Territories. In Settlers in Contested Lands: Territorial Disputes and Ethnic Conflicts, edited by Oded Haklai and Neophytos Loizides, 1-16. Stanford, CA: Stanford University Press. 
Han, Enze, and Harris Mylonas. 2014. Interstate Relations, Perceptions, and Power Balance: Explaining China's Policies Toward Ethnic Groups, 1949-1965. Security Studies 23 (1):148-81.

Hazarika, Sanjoy. 2001. A Question of Outsiders: Bangladesh, Myanmar and Bhutan. In Demography and National Security, edited by Myron Weiner and Sharon Stanton Russell, 228-55. New York: Berghahn Books.

Herbst, Jeffrey. 1990. War and the State in Africa. International Security 14 (4):117-39.

Honaker, James, Gary King, and Matthew Blackwell. 2011. Amelia II: A Program for Missing Data. Journal of Statistical Software 45 (7):1-47.

Horowitz, Donald L. 1985. Ethnic Groups in Conflict. Berkeley, CA: University of California Press.

Human Rights Watch. 2000. Burma/Bangladesh: Burmese Refugees in Bangladesh: Still No Durable Solution. New York: Human Rights Watch.

Huth, Paul K. 1998. Standing Your Ground: Territorial Disputes and International Conflict. Ann Arbor, MI: University of Michigan Press.

Kalyvas, Stathis N. 2006. The Logic of Violence in Civil War. New York: Cambridge University Press. Keegan, John. 1993. A History of Warfare. New York: Knopf.

Kitamura, Shuhei, and Nils-Petter Lagerlöf. 2015. Natural Borders. Seminar Paper 773. Stockholm: Institute for International Economic Studies.

Kocs, Stephen A. 1995. Territorial Disputes and Interstate War, 1945-1987. Journal of Politics 57 (1):159-75.

Laitin, David D. 1998. Identity in Formation: The Russian-speaking Populations in the Near Abroad. Ithaca, NY: Cornell University Press.

Lee, Melissa M. 2018. The International Politics of Incomplete Sovereignty: How Hostile Neighbors Weaken the State. International Organization 72 (2):283-315.

Li, Chengrui. 1985. The Reliability of China's 1982 Population Census Data. Paper presented at the International Population Conference, June, Florence.

Li, Wenshu. 2017. Goodbye, Lake Changshou. [In Chinese] Available at <https://botanwang.com/articles/ 201709/\%E5\%88\%AB\%E4\%BA\%86\%EF\%BC\%8C\%E9\%95\%BF\%E5\%AF\%BF\%E6\%B9\%96. html>. Accessed 9 January 2018.

Liang, Zai, and Michael J. White. 1996. Internal Migration in China, 1950-1988. Demography 33 (3):375-84.

Lichtenheld, Adam. 2018. Explaining Population Displacement Strategies in Civil War: A Cross-National Analysis. Available at <https://papers.ssrn.com/sol3/papers.cfm?abstract_id=3287998> accessed 02/02/ 19.

Lustick, Ian. 1993. Unsettled States, Disputed Lands: Britain and Ireland, France and Algeria, Israel and the West Bank-Gaza. Ithaca, NY: Cornell University Press.

Lüthi, Lorenz M. 2010. The Sino-Soviet Split: Cold War in the Communist World. Princeton, NJ: Princeton University Press.

Ma, Rong. 2011. Population and Society in Contemporary Tibet. Hong Kong: Hong Kong University Press.

Mao, Zedong. 1974. Mao Tse-tung Unrehearsed: Talks and Letters, 1956-71. London: Penguin.

Martin, Terry. 2001. Stalinist Forced Relocation Policies. In Demography and National Security, edited by Myron Weiner and Sharon Stanton Russell, 305-39. New York: Berghahn Books.

McGarry, John. 1998. "Demographic Engineering”: The State-directed Movement of Ethnic Groups As a Technique of Conflict Regulation. Ethnic and Racial Studies 21 (4):613-38.

McNamee, Lachlan. 2018. Mass Resettlement and Political Violence: Evidence from Rwanda. World Politics 70 (4):595-644.

Meng, Xin, Nancy Qian, and Pierre Yared. 2015. The Institutional Causes of China's Great Famine, 19591961. The Review of Economic Studies 82 (4):1568-611.

Morelli, Massimo, and Dominic Rohner. 2015. Resource Concentration and Civil Wars. Journal of Development Economics 117 (C):32-47.

Morland, Paul. 2014. Demographic Engineering: Population Strategies in Ethnic Conflict. Abingdon, UK: Routledge.

Mylonas, Harris. 2012. The Politics of Nation-Building: Making Co-Nationals, Refugees, and Minorities. Cambridge, UK: Cambridge University Press. 
Natali, Denise. 2015. Settlers and State-building: The Kirkuk Case. In Settlers in Contested Lands: Territorial Disputes and Ethnic Conflicts, edited by Oded Haklai and Neophytos Loizides, 114-40. Stanford, CA: Stanford University Press.

Posner, Daniel N. 2005. Institutions and Ethnic Politics in Africa. Cambridge, UK: Cambridge University Press.

Pounds, Norman. 1972. Political Geography. New York: McGraw-Hill.

Robinson, Thomas W. 1972. The Sino-Soviet Border Dispute: Background, Development, and the March 1969 Clashes. American Political Science Review 66 (4):1175-202.

Sahlins, Peter. 1989. Boundaries: The Making of France and Spain in the Pyrenees. Berkeley, CA: University of California Press.

Salehyan, Idean. 2009. Rebels Without Borders. Ithaca, NY: Cornell University Press.

Sambanis, Nicholas, Stergios Skaperdas, and William C. Wohlforth. 2015. Nation-building Through War. American Political Science Review 109 (2):279-96.

Schultz, Kenneth A. 2017. Mapping Interstate Territorial Conflict: A New Dataset and Applications. Journal of Conflict Resolution 61 (7):1565-90.

Senese, Paul D. 2005. Territory, Contiguity, and International Conflict: Assessing a New Joint Explanation. American Journal of Political Science 49 (4):769-79.

Simmons, Beth A. 2005. Rules Over Real Estate; Trade, Territorial Conflict and International Borders as Institutions. Journal of Conflict Resolution 49 (6):823-48.

Steele, Abbey. 2011. Electing Displacement: Political Cleansing in Apartadó, Colombia. Journal of Conflict Resolution 55 (3):423-45.

Teitelbaum, Michael S. 2015. Political Demography: Powerful Trends Under-attended by Demographic Science. Population Studies 69 (S1):S87-S95.

Tilly, Charles. 1990. Coercion, Capital and European States: AD 990-1990. Cambridge, MA: Basil Blackwell.

Toft, Monica Duffy. 2003. The Geography of Ethnic Violence: Identity, Interests, and the Indivisibility of Territory. Princeton, NJ: Princeton University Press.

Valentino, Benjamin, Paul Huth, and Dylan Balch-Lindsay. 2004. "Draining the Sea": Mass Killing and Guerrilla Warfare. International Organization 58 (2):375-407.

Vasquez, John A. 1993. The War Puzzle. Cambridge, UK: Cambridge University Press.

Vasquez, John, and Marie T. Henehan. 2001. Territorial Disputes and the Probability of War, 1816-1992. Journal of Peace Research 38 (2):123-38.

Weidmann, Nils B. 2009. Geography As Motivation and Opportunity: Group Concentration and Ethnic Conflict. Journal of Conflict Resolution 53 (4):526-43.

Weiner, Myron, and Sharon Stanton Russell. 2001. Introduction. In Demography and National Security, edited by Myron Weiner and Sharon Stanton Russell, 1-17. New York: Berghahn Books.

White, Lynn T. 1979. The Road to Urumchi: Approved Institutions in Search of Attainable Goals During Pre-1968 Rustication from Shanghai. The China Quarterly 79:481-510.

Xu, Yiqing. 2017. Generalized Synthetic Control Method: Causal Inference with Interactive Fixed Effects Models. Political Analysis 25 (1):57-76.

Zhang, Anfu. 2011. The Northwestern Frontier During the Sino-Soviet Military Standoff: Xinjiang Production and Construction Corp to Enhance Military Stock. Contemporary Studies of Chinese History 18 (4):100-28.

Zhukov, Yuri M. 2015. Population Resettlement in War: Theory and Evidence From Soviet Archives. Journal of Conflict Resolution 59 (7):1155-85. 